\title{
Contribution to Sustainability and the National Economy Through Recycling Waste Paper from Istanbul's Hotels in Turkey
}

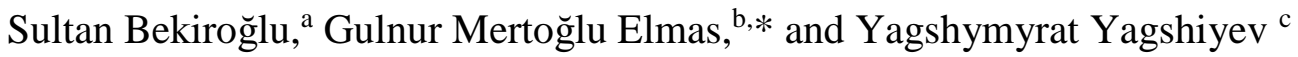 \\ Obtaining cellulose from recyclable waste paper contributes to the \\ sustainability of forest resources, water and energy savings, and the \\ reduction of environmental pollution. However, waste paper collected \\ under inappropriate conditions for recycling can be degraded in a short \\ time, thus becoming economically useless. This study examined the \\ factors affecting source-separated collection processes of waste paper in \\ Istanbul hotels, as well as the correlation among these factors. The \\ economic value of the assumed benefits of source-separated waste paper \\ was also calculated. To achieve these objectives, various inputs and \\ methods were used, including the percent tabulation technique and the \\ chi-square independence test. As a result, it was determined that $70 \%$ of \\ managers and employees of Istanbul hotels were sensitive to recycling \\ waste paper, but they were not aware of the entire benefits of waste paper \\ recycling. It was also determined that because of waste paper recycling, \\ 18 thousand trees, 5 million kWh of electricity, 3 thousand tons of water, \\ and 1.3 thousand tons of fuel oil were saved, and the generation of 27 \\ thousand tons of $\mathrm{CO}_{2}$ was prevented annually. Hotels in Istanbul provide \\ the economy with an annual average of 752 tons of waste paper, which \\ corresponds to $78 \%$ of the foreign trade deficit of Turkey's paper and paper \\ products sector in the last five years.
}

Keywords: Sustainability; Waste paper recycling; Economic contribution; Istanbul's hotels

Contact information: a: Department of Forestry Economics, Department of Forest Engineering, Faculty of Forestry, University of Istanbul, Istanbul, Turkey; $b$ : Department of Forest Products Chemistry and Technology, Department of Forest Industry Engineering, Forestry Faculty, Istanbul University, Istanbul, Turkey; c: Department of Forest Industry Engineering, Faculty of Forestry, University of Istanbul, Istanbul, Turkey; *Corresponding author: mertoglug@istanbul.edu.tr

\section{INTRODUCTION}

All global assets, notwithstanding their current economic usage status, are qualified as resources and are divided into three categories: human, cultural, and natural resources. The first two are created by mankind, whereas the latter does not depend on mankind for creation. Nevertheless, people have a strong influence on the quality and quantity of available natural resources (Kula 1994).

Mankind consumes resources and generates waste at unprecedented amounts. This impacts the environment and gives way to various consequences such as the inability to maintain sustainable management of natural resources, reduction of crop productivity due to climate change, and the reduction of biodiversity and contamination of living environments such as air-water-soil. These outcomes result in many social, economic, technological, and environmental changes with unpredictable consequences (European Commission 2012; The Royal Society 2012). 
A certain part of nonrenewable resources (e.g. natural gas, radioactive substance) becomes depleted naturally, whereas another part (e.g. coal, petroleum) is depleted by human consumption. Considering human impact, a similar situation can be seen for renewable natural resources, which otherwise can sustain themselves in nature. Mankind is one of the leading factors in exhaustion of some renewable natural resources such as forests and animals. The natural resources are basic inputs of economic and technological development. As the development competitiveness of countries and the rapidly growing population constantly raise their demand for natural resources, new reserves are added in limited quantities to existing natural resource stocks. As a result, the supply of natural resources used as inputs to meet human needs remains always insufficient (Field 1994; Özsabuncuoğlu and Uğur 2005).

According to conventional understanding of development, rapid industrialization results in rapid economic growth. However, this simple rule has many complications in practice, such as an increase in environmental impacts. For this reason, starting from the early 1960s, alternative development approaches have been explored, especially in developed countries (Doğaner Gönel 2002; TÜBITAK 2003). The Club of Rome, in an attempt to attract interest on the subject, prepared a report indicating that many of the natural resources that are critical to mankind's survival will be depleted in one or two generations. The exit strategy proposed was "sustainability," as it was first stated in the Brundtland Report of 1987. In this report, which received intensive interest throughout the globe, an answer to the following question was sought: "How can the aspirations of world nations for a better life be reconciled with the threats of limited natural resources and environmental degradation?" The suggested answer was "sustainable development". The definition of sustainable development according to the Brundtland Report was: "the development that meets the needs of the present without compromising the ability of future generations to meet their own needs". This definition brings a new approach to the natural resources that exceeds the current value of them and views natural resources from the viewpoint of equality among generations. The concept of sustainable development was further advanced later. One of such advancements requires the sustainability to be evaluated with not only economical but also with social and environmental aspects to it in a three-dimensional approach. Another development in the process was that the sustainability is to be examined in two categories as "strong sustainability" and "weak sustainability" (Daly 1993; Kula 1994; Faber et al. 1996; van Kooten and Bulte 2000; Cunningham et al. 2003; Conrad 2006; Y1kmaz 2011).

Differing from conventional development approaches, alternative development approaches focus on providing sustainability of three aspects of social welfare, i.e. economic, social, and environmental aspects. However, the goals of these three aspects may sometimes conflict. For instance, the use and consumption of natural resources and generation of waste is required for economic sustainability, while such activities expose environmental sustainability to risk. Nevertheless, remarkable efforts have been made to solve the problems that are created from contradicting goals. One such effort involves "recovering recyclable wastes as secondary raw materials for economic use" as a means of preventing environmental pollution and excessive use of natural resources (Kula 1994; van Kooten et al. 2000; Cunningham et al. 2003).

According to estimations, mankind generate an average of 1.15 trillion $\mathrm{kg}$ of waste per year. Previous practices of unsanitary disposal and incineration of such waste, as it was accepted as mere garbage, increased environmental pollution. For this reason, waste management practices began to be implemented. These practices stipulate the use of 
sanitary landfills, composting, and re-use, recycling, and recovery methods, which ensures the re-introduction of half of these wastes into the economy. For instance, it is estimated full implementation of EU waste legislation would save $€ 72$ billion a year, increase the annual turnover of the EU waste management and recycling sector by $€ 42$ billion, and create over 400,000 jobs by 2020 (European Commission 2012).

Given the advantages created by the recovery of recyclable waste, such as the creation of job opportunities, effective use of natural resources, creation of economic value, and improvement of the environment, the recycling sector has been a fruitful effort. In the recycling sector, there are many stages, such as minimization, source-separation, storage, transportation, recovery, recycling, and disposal of waste. As determined from ongoing study, recycling is an important part of environmental protection policy. Because of this policy, properly handled and sorted waste shall no longer be categorized as an environmental hazard and becomes economically valuable, which serves as a basis for sustainable development. For this reason, the "National Recycling Strategy Document and Action Plan 2014-2017" was prepared in Turkey to improve the efficiency of the recycling sector (TR Ministry of Science, Industry and Technology 2013). Mrayyan and Hamdi (2006), and Y1lmaz and Bozkurt (2010) report that, while developing countries still conduct debates concerning the disposal of waste, developed countries have already started using advanced practices, such as composting and recycling.

Paper is a material that has tens of thousands of different uses. There is a positive correlation between the per capita consumption of paper and development level of a country. The main problems of the paper industry include high costs, sustainability, and supply of recyclable raw materials (Pal and Joyce 2017). Forest trees, annual-perennial plants, and recyclable paper waste are all used to obtain cellulose. The use of natural and artificially cultivated plants in large areas to obtain cellulose creates competition for land use among land-based sectors, such as forestry, agriculture, and stockbreeding. Moreover, there is no environmental pollution reduction effect from this type of cellulose production. However, paper pulp obtained from recycling is seen as an important raw material today. Newspapers, corrugated cardboards, magazines, notebooks, and office waste are widely used to obtain paper pulp. This practice is known to have a multitude of positive impacts, such as the protection of forests and other natural resources, energy savings, increased employment, and reduction of environmental pollution (Hubbe 2014; Bekiroğlu and Mertoğlu Elmas 2016; Lee et al. 2016; Mertoğlu Elmas 2016).

Businesses have organizational activities and environmental management units based on technical principles to reduce the negative impacts from generated waste. In the beginning, these units realized their goals through the modification of physical characteristics of products or through the replacement of machinery used to mitigate negative environmental impacts caused by the company. Even though completing technical measurements did not cause any direct impacts on the environment, the structural systems of companies were changed and improved. Businesses have already achieved specialization in various sustainability areas, including environmental training and planning, control and reporting of environmental objectives, and support from upper management. Environmental management used to be considered a volunteer action, whereas it has now become a requirement for many businesses. For these reasons, environmental management has a priority in hotels, just like in all other businesses in Turkey. According to research data, there is a positive correlation between environmental management practices and the financial performance of corporations (Snarr and Pezza 2000; Álvarez Gil et al. 2001). 
This study aims to achieve two objectives. The first objective is to determine the factors that affect the collection practices of source-separated recyclable waste paper at Istanbul's 1- to 5-star hotels (hereinafter referred to as hotels). Specifically, we aim to investigate the source-separated waste paper collection processes, as well as their effects on forest management, environmental policy, water-energy saving, waste management, and attitudes of visitors toward using recycled products along with the correlation between their environmentally-friendly efforts. The second objective is to estimate the total economic value of hotel environmental contributions originated from source-separated collection of recyclable waste paper, among domestic waste generated by activities of Istanbul's hotels. The present study enables determination of obstacles to source-separated collection of recyclable waste paper encountered by hotels (which consume second highest amount of domestic paper products, after houses, and hence generate significant amount of recyclable waste paper) and ways to overcome these obstacles, thus encouraging recycling by showing the economic benefits of waste paper recycling.

\section{Relationship between Hoteling-Tourism Sectors and Sustainable Natural Resources Management Practices}

Tourism and hoteling (hotels) sectors are entangled in an inseparable way. The hoteling industry is accepted to be one of the most important sub-sectors of tourism. For this reason, these two sectors were evaluated together in this section.

The economic, cultural, environmental, and psychological developments that have emerged since the 1950s have made major changes on human habits and needs. One of the consequences of this change is the widespread and intense tourism movement at local and global levels. This rise in the tourism sector's development in the last half of the 20th century continued into the 21st century (Oktayer et al. 2007; SBA 2008; Güneş 2011; Holjevac 2013; UNWTO 2017a).

Today's people are sensitive about the sustainability of natural resources. For this reason, tourism operators understand that they have to prove that they support sustainable natural resource management as opposed to the production activities that affect natural resources in a negative way (Butler 1998; Holjevac 2003; Saatc1 et al. 2013). This awareness has forced tourism businesses to be environmentally friendly. Environmentalism can be defined as an effort to consciously reduce the activities that affect the Earth in the negative. Some examples of these efforts are: reducing resource and energy use, reducing waste generation and contributing to recycling, supporting the use of nontoxic materials, supporting green innovation, and choosing environmentally friendly technologies (Kollmuss and Agyeman 2002; Steg and Vlek 2009; Alnıçık 2010; UNWTO 2017b). Environment-waste management is a multidimensional and interdisciplinary concept, practiced by businesses "firstly by reducing the negative environmental impacts they cause due to their activities and then adopting environmental protection-oriented practices". This concept is also referred to as "green management", "corporate environmentalism", "ecological management", "environmental sensitivity", and "environmentally sensitive management" (Banerjee 2002; Zso'ka 2008; Chan 2010; Aykan and Sevim 2013). This concept is defined by the International Standards Organization (ISO) as "the systematic reduction and, where possible, the elimination of damages that businesses cause or might cause regarding the environment" (ISO 2017).

Today, tourism accounts for $10 \%$ of the world Gross Domestic Product (GDP) and $7 \%$ of global exports. On a global scale, one out of every 10 employees are employed in the tourism sector (UNWTO 2017a). The global tourism income generated in the year 2016 
was US\$1.5 Billion, and it is expected to reach US\$ 2 Billion in 2020. The number of international tourists for the year 2016 was about 1 billion, which is expected to increase to 1.8 Billion by the year 2030 . This is the reason why countries compete to achieve the highest proportion of international tourism revenues (Y1ld1z 2011; UNWTO 2016a,b; Worlbank 2016). On the other hand, it is estimated that the tourism sector is responsible for $5 \%$ of global $\mathrm{CO}_{2}$ emission; that tourism-related air-transportation causes $40 \%$ of environmental pollution that contributes to global climate change, whereas hotels and other hoteling types causes $20 \%$, and other means of transport (cars, railways, etc) and recreational activities cause $40 \%$. These figures indicate that the sustainability policies in the tourism sector are still insufficient (OECD 2010). This being said, there are international efforts to reduce or eliminate these damages caused by tourism activities. One such effort is the declaration of the International Year of Sustainable Tourism for Development and the stipulation of a stronger role for tourism in "effective use of resources, protection of environment and fighting against climate change". In this respect, the "Tourism and Future Energy: Unlocking low-carbon growth opportunities" was held in Astana - Kazakhstan June 26-27, 2017. The final declaration of this conference acknowledged the critical importance of "greening" and "decarbonizing" in tourism in the creation of a competitive and sustainable sector (OECD 2010; Canbay 2011; UNWTO 2017b).

It is a known fact that one of the most significant environmental outcomes of the rapidly growing tourism and hoteling sector is deforestation. Some of the most important pressures of tourism sector on the forests are construction of hoteling, transportation, sportive, and entertainment facilities on cleared forestry areas; and damages to nature and disruption of wildlife are caused by recreational activities (Madan and Rawatu 2000; Kasim and Scarlat 2007; Leslie 2007; Kuvan 2010; Y1ldız 2011; Qui 2017). Hotels, one of the most basic elements of tourism (OECD 2010), have been regarded as the cause for a large part of forest destruction caused by this sector. Kuvan (2005) examined the land allocation to a tourism center with a capacity of 25,354 beds in Antalya Province, which is the second most important tourism city in Turkey after Istanbul. According to the survey, 355 hectares of land were allocated to the related tourism center, $40 \%$ of which were forests; 12,319 $(30.5 \%)$ of the 40,405 trees of the forestry area allocated for the construction of touristic facilities have been cut, and the increased number of tourists and their activities have caused pollution in the surrounding forests and shorelines. On the other hand, tourism and hoteling sectors are very sensitive to environmental destruction (UNWTO 2016b). For this reason, the businesses in the sector have started to establish "Environmental-Waste Management Systems" to maintain their competitive strength and to increase customer satisfaction (Didin and Köroğlu 2008). The factors that affect the environmental (waste) management systems of businesses in tourism-hoteling sector are given in Fig. 1. 


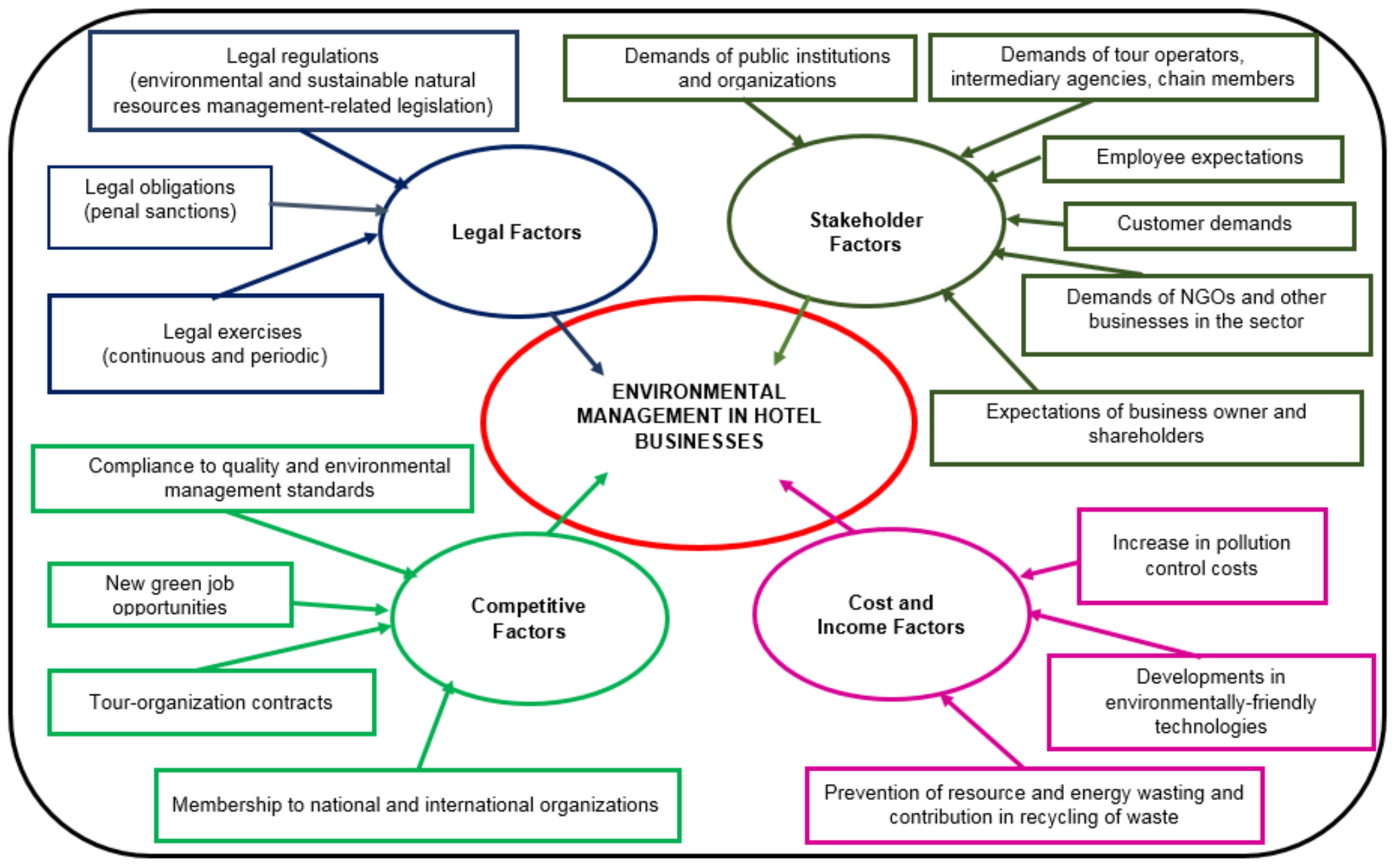

Fig. 1. Factors affecting environmental-waste management systems of businesses in tourism-hoteling sectors; Source: Aykan and Sevim (2013), Berry and Rondinelli (1998) 
Figure 1 was designed to categorize the factors affecting the environmental management systems of the businesses. Therefore, the arrows in the figure should not be deemed as the direction of effect. There are many interactions both between the factors and the factors and environmental management systems on different directions and at various scales. According to Zhang et al. (2008), pressures from the supply chain, clients, and associations (societies) have positive impacts on the environmental management performance, whereas legal regulations, unless there are compliance issues, do not positively affect the environmental management performances of hotels. Said study also states that the activity of environmental management system is affected by the size of the business and that the large-scale hotels are more active in environmental management engagement.

Tourism can have both positive and negative impacts. Tourism represents $35 \%$ to $70 \%$ of the global export of services in some developing countries, but tourism often requires unsustainable consumption practices that endangers ecosystems and natural resources. Hence, there is a need for conscious waste management and greener hotels (SBA 2008).

Hotels in Turkey are categorized as "enterprises that have pollution effects on the environment". Pursuant to the Regulation on Control of Water Pollution, Regulation on Control of Air Pollution, Waste Management Regulation and similar environmental legislation, they are subjected to monitoring and supervision by the Ministry of Environment and Urban Planning and provincial directorates of the Ministry. Waste that can be generated in these hotels, such as waste vegetable oils, packaging waste, hazardous waste, non-hazardous waste, medical waste, waste accumulators, and so on must be collected separated at source and delivered to waste treatment facilities by licensed carriers (Güneş 2011; Aykan and Sevim 2013; Dönmez and Değirmen 2016; TBB). Pursuant to the "Regulation on Control of Packaging Waste" the packaging waste must be collected separated from other waste and delivered to the collection system of the municipality free of charge (THF 2017).

\section{Production and Consumption of Paper in Turkey and the World}

Paper is one of the most consumed products worldwide. As stated before, the per capita consumption of paper increases with the level of development of that given society. For instance, at the beginning of 2005, the per capita paper consumption of low welfare countries was $4.11 \mathrm{~kg}$, whereas it was $227.82 \mathrm{~kg}$ in high welfare countries. In this regard, the statistics indicate a positive correlation between the national income level and paper consumption (Sandalc1lar 2012).

Today, the amount of paper and paper-derivative products produced globally is approximately 274 million tons. Approximately $50 \%$ of this figure consists of package and labelling paper, whereas $28 \%$ is printing or writing paper. It is estimated that the increase of paper production will not stop in future years, and that it will reach 279 million tons by 2018. It is expected that the proportion of packaging, label papers, and cleaning papers will increase as well. Turkey was self-sufficient in terms of paper production up until the 1980s. However, when high-quality paper products began to be imported, domestic paper production started to have problems competing against foreign paper production. In terms of raw materials and technology in the paper production sector, Turkey is a foreigndependent country. Yet, the paper and paper products sector of Turkey has continued to expand. The paper production practices in Turkey are given in Fig. 2 (SKVS 2015; Çevik 2016). 


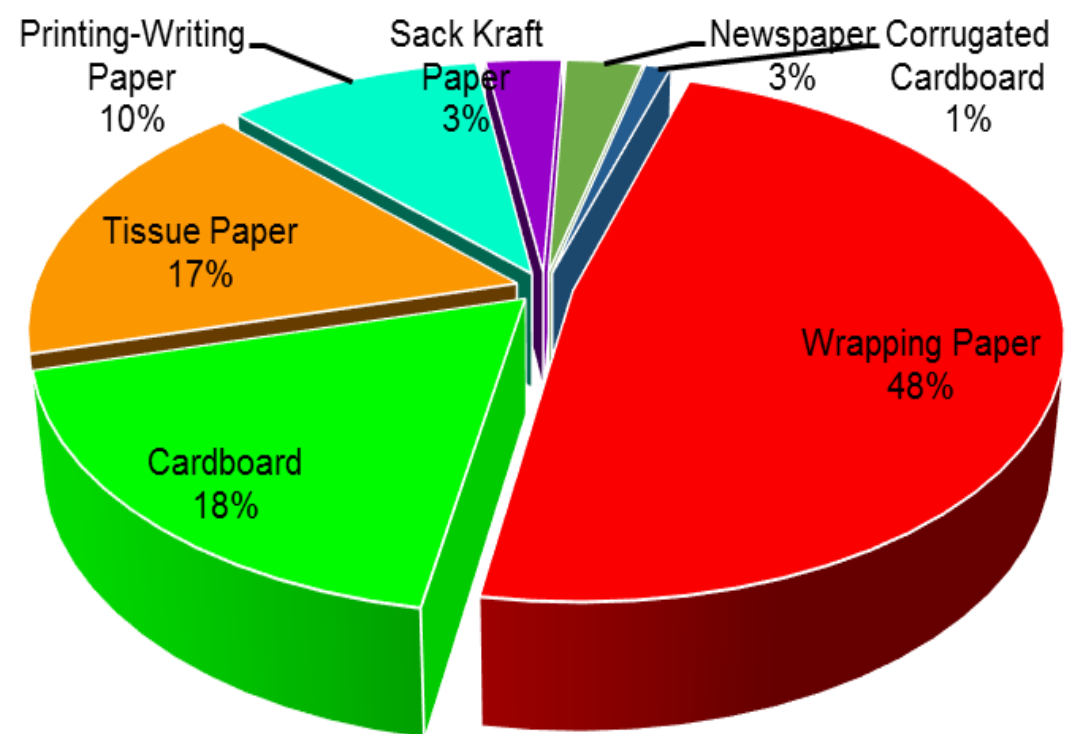

Fig. 2. Paper production rates in Turkey; Sources: Çevik (2016) and SKVS (2015)

As shown in Fig. 2, 66\% of the paper production of Turkey consists of cardboard and packaging. The per capita paper consumption from 1970 to 2005 is given in Table 1 (Sandalc1lar 2012).

Table 1. Per Capita Paper Consumption (kg/year)

\begin{tabular}{|c|c|c|c|c|c|c|c|c|c|}
\hline $\begin{array}{c}\text { Country/Income } \\
\text { Group }\end{array}$ & 1970 & 1975 & 1980 & 1985 & 1990 & 1995 & 2000 & 2005 & $\begin{array}{c}\text { 35-year } \\
\text { Growth } \\
\text { Rate }\end{array}$ \\
\hline Turkey & 6.1 & 10.7 & 12.5 & 13.1 & 19.4 & 24.9 & 35.4 & 50.5 & 75.0 \\
\hline US & 236.8 & 220.1 & 262.9 & 280.5 & 306.3 & 333.4 & 328.7 & 297.1 & 11.4 \\
\hline Canada & 154.1 & 148.6 & 167.0 & 186.9 & 200.5 & 215.2 & 297.1 & 241.9 & 14.3 \\
\hline United Kingdom & 125.9 & 108.7 & 123.0 & 138.4 & 154.2 & 191.7 & 191.5 & 201.2 & 14.5 \\
\hline Japan & 120.4 & 117.1 & 153.9 & 168.6 & 228.9 & 241.1 & 250.8 & 233.5 & 17.6 \\
\hline Germany & 114.1 & 106.2 & 140.7 & 154.8 & 201.8 & 193.9 & 231.8 & 231.6 & 18.5 \\
\hline France & 96.3 & 90.7 & 115.0 & 113.9 & 153.8 & 165.3 & 192.2 & 178.7 & 16.9 \\
\hline High Income & 137.5 & 129.8 & 160.1 & 172.3 & 240.9 & 226.0 & 241.3 & 227.8 & 15.1 \\
\hline Middle Income & 8.5 & 9.7 & 13.2 & 14.9 & 18.3 & 23.8 & 30.8 & 39.1 & 41.6 \\
\hline Low Income & 1.7 & 1.6 & 1.7 & 2.1 & 2.3 & 2.5 & 3.3 & 4.11 & 21.5 \\
\hline Global & 34.0 & 32.1 & 38.0 & 39.7 & 45.5 & 48.7 & 53.5 & 54.5 & 14.5 \\
\hline
\end{tabular}

Source: Sandalcılar (2012).

Upon examination of Table 1, it was determined that the per capita paper consumption has increased $75.04 \%$ in Turkey from 1970 to 2005. Due to this increase, Turkey has increased the paper consumption rates of the middle income countries group, in which Turkey is included. From Table 1, it was concluded that the paper sector of Turkey has growth potential.

\section{Recycling of Waste Paper}

Paper made from plants, such as trees, jute, cannabis, or reeds, was invented by the Chinese. Paper and paper-derivatives are products in high demand in many sectors, but 
chiefly in the printing and packaging sectors. These sectors are categorized as mediumheavy industries, with regards to capital, technology, and energy needs. For this reason, the paper sector is acknowledged as being a high-functioning sector because of the backwards and forwards connections to national economies.

It was previously assumed that technological advancements will cause a reduction in paper consumption, and yet the exact opposite trend has become true. The consumption of paper has increased continuously in rapidly developing countries. Paper producers started to focus on waste paper as an input source because of the insufficiency of natural resources, such as wood, hay, and cotton, which are raw materials for cellulose production, as well as the inconveniences of growing trees, including the long time requirements, increasing environmental pollution, and increasing energy costs. Today, cellulose, the main ingredient of paper, is largely obtained from the recycling of waste paper, instead of cutting down trees (Armağan et al. 2006; Yakut 2012; Virtanen 2013). Moreover, upon obtaining new material by recycling paper and cardboard, there will be less need for landfill area for this solid waste type which will result in reduction of $\mathrm{CO}_{2}$ greenhouse gas emission by $41 \%$ (Micales and Skog 1997), hence contributing in fight against global warming.

Paper is mainly used for newspapers, journals, packaging, and napkins, and then disposed of after use. These products are classified as paper, cardboard, and plasterboards. Some paper, like those used for personal hygiene purposes and tissue products, are not suitable for recycling, but other paper waste can be re-used as secondary raw materials because of their physicochemical properties. For this reason, recyclable waste paper is accepted as a raw material with economic value. The preference for cellulose from forest trees and recycled cellulose in paper products for different countries and regions is given in Fig. 3.

The tendency to recover recyclable waste paper is accelerated with the realization that recycling provides major contributions to certain sustainbility targets, such as zero waste and the sustainability of natural resources. Figure 2 shows that the demand for both fresh wood pulp and recovered fiber has increased in Asia, most notably in China, whereas the demand for fresh wood pulp has decreased and the demand for recovered fiber has increased in Europe and North America. The amount of waste and waste paper that is recycled varies between each country depending on their level of prosperity and environmental sensitivity. Countries with a high level of prosperity have largely achieved zero waste targets. For instance, in Sweden, $99.9 \%$ of domestic waste is recycled (Avfall Sverige 2017). Unfortunately, the proportion of waste recycled in Turkey is currently unknown. 


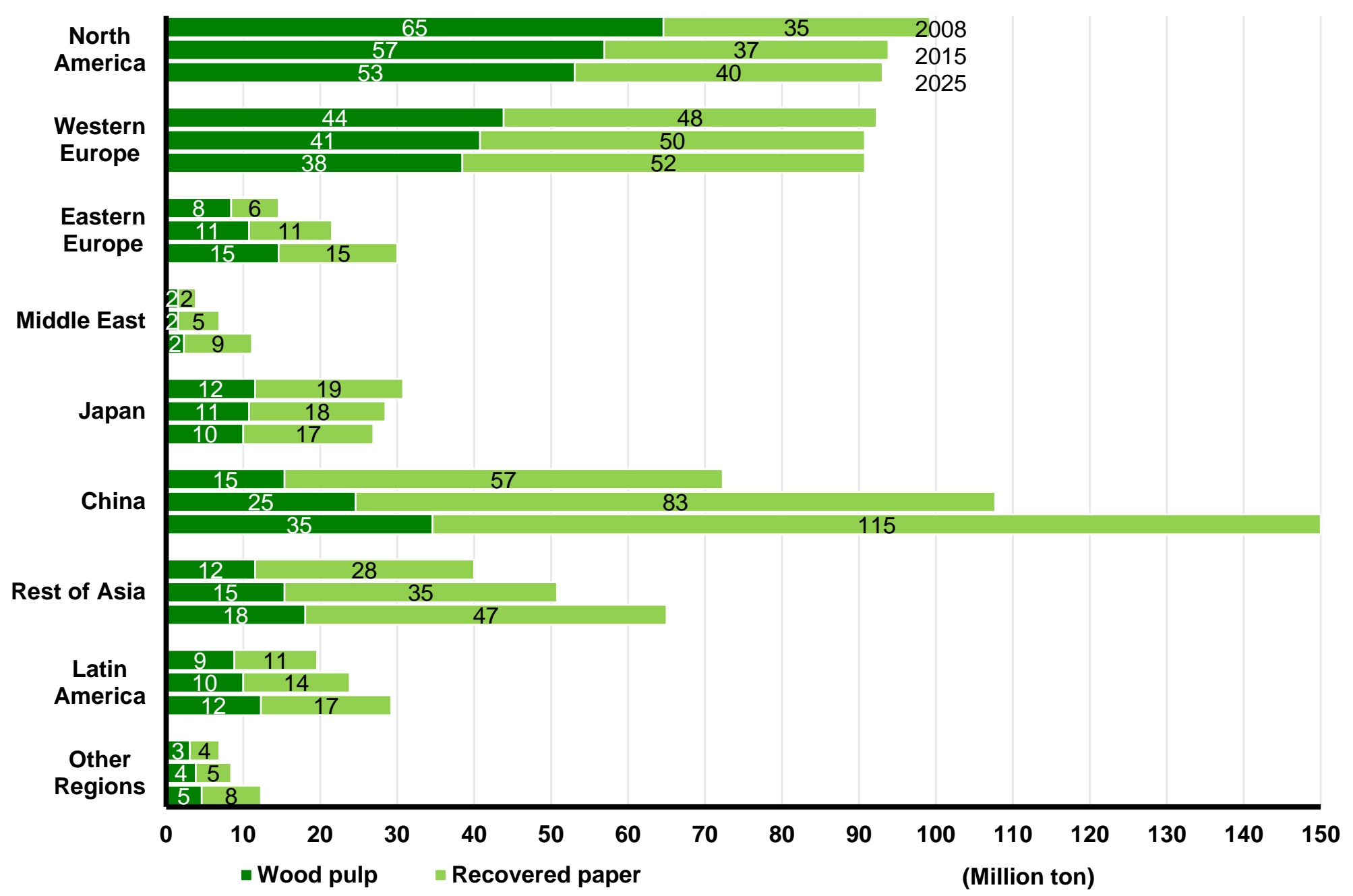

Fig. 3. Past and projected demand for fresh wood pulp and recovered fiber by region; Source: WBCSD (2012) 
The amount and composition of waste varies according to consumption habits, population growth, and standards of living. That being said, it is generally well known that packaging waste constitutes $20 \%$ of the total weight and $50 \%$ of the total volume of all waste, and that paper and paper-derivative packaging waste constitutes a major part of all packaging waste. Considering the ever increasing amount of recyclable waste paper and that waste paper can be re-introduced into the economy through recycling approximately 5 to 7 times (TUROB 2013a; WBCSD 2016; AGED 2017), obtaining cellulose from waste paper is extremely important for zero waste and sustainable natural resource management goals.

The base component of paper is cellulose. If cellulose is obtained solely from raw fiber, annual and perennial plant sources are consumed in higher amounts. For centuries, forests and other ecosystems wherein plant sources are found have been exploited as sources of raw fiber to produce paper. However, such exploitation has put the sustainability of natural resources in danger. Thus, it is important that cellulose derived from waste paper also be used for paper production, which has in fact been implemented, turning waste paper into a valuable raw material for national economies (Çevik 2016).

\section{EXPERIMENTAL}

\section{Description of Study Area}

Due to its historical, cultural, economic and scientific value, the study area, i.e. Istanbul (Fig. 4) receive high attraction from domestic and international tourists. Considering total number of visitors and hotel-bed capacity, Istanbul is the tourism leader of Turkey and is one of the major destinations in the world (TUROB 2013a).

Istanbul is located in Marmara Region of Turkey, which is the most advanced region of the country in terms of population, industrialization, and economic development levels. As of the year 2017, the population of Istanbul reached 15 million, hence making the city one of the most populated of the world (TSI 2017). Tourism and hoteling sectors have shown a great development in Turkey especially after 1980s and significantly contributed in reducing unemployment and improving balance of payments. The share of tourism income in gross national product was only $0.1 \%$ in the $1960 \mathrm{~s}$, whereas it reached an average of $4 \%$ in the period of 2010 to 2016. For this reason, the tourism sector has been incentivized as a priority sector in Development Plans (Çımat and Bahar 2003; Özsabuncuoğlu and Uğur 2005; OECD 2010). Despite declining number of tourists arrival in some years, Turkey has been one of the top 10 countries of the world in terms of attracting foreign tourists in the last decade. In 2016, the total annual number of tourists in Turkey was 36.5 million and tourism revenues were 26.8 million US\$, (UNWTO 2017a; TR Ministry of Culture and Tourism 2017; Turizm Ajans1 2017; UNWTO 2016a). According to the average figures of the last five years' period (2012-2016) Turkey receives 33.02 million and Istanbul receives 10.7 million tourists (TR Ministry of Culture and Tourism 2017). As it can be seen, approximately $33 \%$ of the tourists visited Turkey were hosted in Istanbul. Given 15 million population of the city, Istanbul received visitors amounting approximately $71 \%$ of its population. 


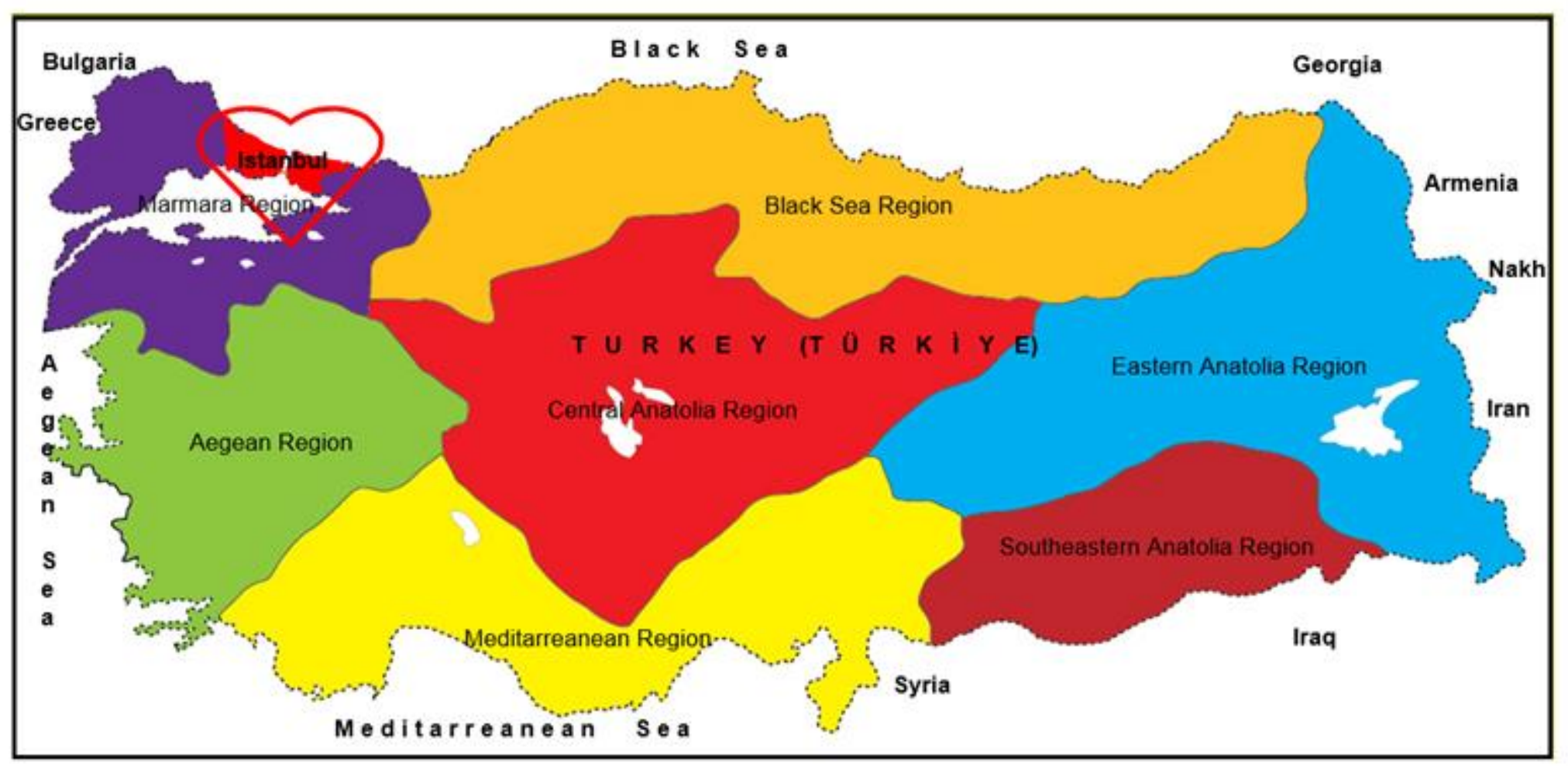

Fig. 4. Study area of Istanbul, Turkey; source: Forumtr (2017) 
Turkey ranks third, with 1.3 million beds, among European countries in terms of bed capacity (TUROB 2013a). Istanbul has the highest number of hotels among all cities of Turkey; $55 \%$ of night stays in Turkey are held in accommodation facilities, whereas $29 \%$ of night stays in accommodation facilities are in Istanbul. According to 2013 data, the number of rooms in Istanbul is 75,100 and the total number of beds is around 152,500. Distribution of these hotels by the number of stars is given in Table 2, and the room capacities by the districts are given in Table 3 (TUROB 2013a). Considering that approximately half $(46 \%)$ of night stays in Istanbul are held in accomodation facilities, the importance of hotels for tourism and Turkey is evident (TUROB 2013b).

The residential, commercial, and industrial areas of Istanbul are mostly located in the south of the city and in the north there are forests and water catchment basins. However, forests and water basins in the north have been destroyed as a result of high rents, transportation, settlement, and industrial uses. Only a small part of such destroyed forestry areas was rehabilitated and recovered. Deforested areas and damaged forestry areas are important for meeting Istanbul's need for sanitary landfill. The solid wastes in Istanbul were poured into the sea until 1953 and then stored irregularly in places nearby the city (Karakaya 2008).

In terms of residential, commercial, and industrial settlements, there are differences between the European side and the Anatolian side of Istanbul. The European side is one of the oldest settlements in the world and was the capital of multiple empires established in this land. As a result, the European side is superior to the Anatolian side in terms of settlement, trade, and industrial activities. However, this superiority has become a disadvantage in terms of traffic, environmental pollution, and destruction of natural resources (TR Ministry of Culture and Tourism 2017).

Hotels can be classified according to various perspectives (for instance the authority towards which they are responsible (supervisiory authority)). Hotels in Turkey are divided into two groups according to their supervisiory authoriy: 1-Hotels that have a Business Permit issued by the TR Ministry of Culture and Tourism. The hotels in this group are monitored by TR Ministry of Culture and Tourism and their activities are subjected to permission by this ministry. 2-Hotels that do not have a Business Permit issued by TR Ministry of Culture and Tourism. Hotels in this group are subject to regional regulations. The hotels in Turkey are also categorized by the qualities of the service provided: starred hotels, apart hotels, boutique hotels, hostels, motels, resorts, boarding houses and so on (TUROB 2013a).

Table 2. Distribution of Istanbul's Hotels by the Number of Stars (2013)

\begin{tabular}{|c|c|c|c|c|c|c|c|c|c|c|}
\hline & \multicolumn{10}{|c|}{ Hotel Types } \\
\cline { 2 - 12 } & $\begin{array}{c}5 \\
\text { Stars }\end{array}$ & $\begin{array}{c}4 \\
\text { Stars }\end{array}$ & $\begin{array}{c}3 \\
\text { Stars }\end{array}$ & $\begin{array}{c}2 \\
\text { Stars }\end{array}$ & $\begin{array}{c}1 \\
\text { Star }\end{array}$ & Apart & Boutique & Hostel & Motel & Others \\
\hline $\begin{array}{c}\text { European } \\
\text { Side }\end{array}$ & 48 & 95 & 86 & 41 & 8 & 2 & 13 & 1 & 1 & 1,253 \\
\hline $\begin{array}{c}\text { Anatolian } \\
\text { Side }\end{array}$ & 14 & 12 & 6 & 1 & 1 & 1 & 3 & 0 & 0 & 118 \\
\hline Total & 62 & 107 & 92 & 42 & 9 & 3 & 16 & 1 & 1 & 1,371 \\
\hline \multicolumn{7}{|l|}{$\begin{array}{c}\text { Number of hotels in Istanbul that have a Business Permit by TR Ministry of Culture and Tourism: } \\
1,717\end{array}$} \\
(European Side: 1,548; Anatolian Side: 169)
\end{tabular}

Source: TUROB (2013a) 
Table 3. Distribution of Istanbul Hotels Total Room Capacity by District

\begin{tabular}{|c|c|c|c|c|c|}
\hline \multicolumn{3}{|c|}{ European Side } & \multicolumn{3}{c|}{ Anatolian Side } \\
\hline District & $\begin{array}{c}\text { Percentage } \\
(\%)\end{array}$ & $\begin{array}{c}\text { Number of } \\
\text { Rooms }\end{array}$ & District & $\begin{array}{c}\text { Percentage } \\
(\%)\end{array}$ & $\begin{array}{c}\text { Number of } \\
\text { Rooms }\end{array}$ \\
\hline Fatih & 33 & 19,821 & Pendik & 27 & 4,054 \\
\hline Beyoğlu & 19 & 11,412 & Kadıöy & 24 & 3,604 \\
\hline Şişli & 14 & 8,409 & Ataşehir & 13 & 1,952 \\
\hline Beşiktaş & 9 & 5,406 & Üsküdar & 9 & 1,352 \\
\hline Bakırköy & 5 & 3,003 & Beykoz & 7 & 1,051 \\
\hline Others & 20 & 12,012 & Maltepe & 6 & 901 \\
\hline \multicolumn{7}{|c|}{ The total number of beds of hotels in Istanbul 75,079 } \\
\hline Total & 100 & 60,063 & Others & 14 & 2,102 \\
\hline \multicolumn{7}{|c|}{ European Side: 60,063; Anatolian Side: 15,016$)$} \\
\hline
\end{tabular}

Source: TUROB (2013a)

As shown in Table 3, the total number of hotel rooms in Istanbul is 75,079 . However an increase by $25 \%$ is planned (TUROB 2013a).

Since 1995, the Istanbul Environmental Protection and Waste Material Recycling Industry and Trade Corporation (İSTAÇ) has been charged with the collection of recyclable paper waste in Istanbul, and the company's business includes solid waste, medical waste, and afforestation. İSTAÇ produces an average annual profit of US \$2 to 2.5 million per annum by selling fuel derived from waste, compost (fertilizer) and electric energy and provides employment opportunities of up to 5,000 persons with a level of education as low as $75 \%$ (İSTAÇ $2017 \mathrm{a}, \mathrm{b}, \mathrm{c}$ ).

While the recycling rate of packaging waste in Turkey was $40 \%$ in 2000 s, it is aimed to increase this ratio up to $54 \%$ in 2010s (TR Ministry of Environment and Forest 2008).

\section{Materials and Methods}

To calculate the economic contribution of source-separated waste paper collection in hotels with touristic licenses, corporate records and statistical data were used.

The questionnaire filled out by the participants consisted of 33 questions in four groups that included: General Environmental Management (5 questions), Personnel Responsibilities (5 questions), Energy Consumption (10 questions), and Waste Management (13 questions).

Hotels in the present study were selected among starred hotels which are members of the Hotel Association of Turkey (TUROB 2013a). This preference was based on the fact that $80 \%$ of Istanbul's hotels are members of TUROB and starred hotel members constitute 90\% of TUROB's members (TUROB 2013b). Thus, in order to determine the number of hotels which would be required to answer the survey (sample size) (the number of units in the universe is known) the following Formula 1 was used,

$$
n=\frac{N \cdot P \cdot Q \cdot Z_{\alpha}^{2}}{(N-1) \cdot d^{2}}
$$

where $N$ is the size of the universe (325), $P$ is the number of observations of the property sought within the universe (0.5), $Q$ is the rate of absence of the property sought within the Universe (0.5), $Z_{\alpha}$ is the value (1.96) of the confidence level (95\%), and $d$ is the sampling 
error (0.1). Calculation of these figures gave a sample size of 96 (Altunışık et al. 2005). Assuming that there may occur some errors in filling the survey forms, the sample size was increased to 100 to remain on the safe side.

In order to obtain data on variables concerning the first objective of the study, 100 hotels among TUROB member, starred hotels were selected by a random sampling method. The survey was conducted on these hotels by face-to-face interviews between January and April 2015. The survey form prepared consisted 33 questions related to environmental protection and sustainable natural resource management practices of hotels. The questions in the survey form were arranged in a way to question study variables given in the Table 4.

\section{Table 4. Variables of the Study}

\begin{tabular}{|c|}
\hline $\begin{array}{c}\text { A) General Environmental Management: } \\
\text { X1: Participation in green environment program } \\
\text { X2: Having an environmental policy in place } \\
\text { X3: Environmental performance measurement } \\
\text { X4: Preference of environmentally-friendly products for business } \\
\text { X5: Preference of environmentally-sensitive service providers }\end{array}$ \\
\hline $\begin{array}{c}\text { B) Personnel and Environmental Responsibility: } \\
\text { X6: Employment of an environment coordinator } \\
\text { X7: Support of existing personnel's training on environment-related subjects } \\
\text { X8: Consideration of environmental training as a criterion for employment } \\
\text { X9: Having a set of criteria for evaluating environmentally-sensitive personnel } \\
\text { X10: Provision of a green space for personnel }\end{array}$ \\
\hline $\begin{array}{c}\text { C) Energy and Natural Resources Savings: } \\
X 11: \text { Energy management program } \\
X 12: \text { Use of environmentally-friendly light bulbs } \\
X 13 \text { : Savings on lighting } \\
X 14: \text { Automatic lighting control } \\
X 15: \text { Reduction of hot water consumption } \\
\text { X16: Program in place to ensure minimum use of hot water } \\
\text { X17: Use of apparatus on taps and showers for water saving } \\
\text { X18: Automatic control of heating-cooling systems } \\
X 19: \text { Prevention of tap leaking } \\
\text { X20: Pioneering in water and electricity savings }\end{array}$ \\
\hline $\begin{array}{l}\text { D) Solid Waste and Waste Paper Recycling: } \\
\text { X21: Having a program to minimize waste generation in place } \\
\text { X22: Having a solid waste recycling system } \\
\text { X23: Availability of recycling collection bins at various points in the hotel } \\
\text { X24: Complying with legal obligations to process relevant waste } \\
\text { X25: Use of recycled paper products } \\
\text { X26: Informing clients about environmental facilities } \\
\text { X27: Placing recycling bins in attractive locations } \\
\text { X28: Sending recyclable waste paper to recycling plants } \\
\text { X29: Periodic delivery of collected waste paper to recycling plants } \\
\text { X30: Use of both sides of printing paper }\end{array}$ \\
\hline $\begin{array}{c}\text { E) Level of Knowledge on Recycling of Waste Paper } \\
\text { X31: Mode of recyclable waste paper collection } \\
\text { X32: Knowledge on benefits of recycling one ton of recyclable waste paper } \\
\text { X33: Knowing that }>50 \% \text { of all recyclable waste is waste paper }\end{array}$ \\
\hline
\end{tabular}

To assess the survey data, descriptive analysis techniques (percentage and crosstab tabulation) and non-parametric relation analysis technique (chi-square test of 
independence) were used. In non-parametric relation analysis, 95\% of confidence level was based and the correlation between the variables given in the Table 3 was determined in line with zero and study hypothesis $\left(\mathrm{H}_{\mathrm{a}}\right)$ :

$\mathrm{H}_{0}$ : There is no statistically significant relationship between study variables.

$\mathrm{H}_{\mathrm{a}}$ : There is a statistically significant relationship between study variables.

In this correlation analyses when Asymp. Sig. (2-sided) (p) values (p)<0.05, the result is accepted as $\mathrm{H}_{\mathrm{a}}$.

The software SPSS 17.0 (SPSS Statistics for Windows, Version 17.0. Chicago: SPSS Inc.) was used for these statistical analyses.

In order to achieve the second objective of the study, i.e. to determine the value of the environmental benefits created by Istanbul's hotels by source-separated collection of waste paper, three propositions (assumptions) were assumed and then a process involving 5 stages was as follows.

The assumptions accepted for the second objective are as follows:

1) The number of rooms in Istanbul remained unchanged from 2013 to 2015, and the room occupancy rate in 2015 was full.

2) The total economic value of environmental benefits, in the form of only wood, water, electricity, $\mathrm{CO}_{2}$ and solid waste, is sufficient to achieve a judgment on the contribution of the recycling of recyclable waste paper to the country's economy.

3) The hotels with a Business Permit by TR Ministry of Culture and Tourism will be considered and 1 tons of recyclable waste paper will be obtained per each 100 rooms in these hotels.

As it is seen, only a certain part of positive effects of waste recycling were considered in the study. In fact there are a multitude of environmental and economic benefits of waste recycling, including the possibility of creating new employment opportunuties and new bussinesses and reducing health expenses by providing a clearer environment. For this reason, the conclusions of this study should be viewed as the tip of the iceberg.

Calculation of Total Economic Value (TEV) of 7 environmental benefits created by source-separate collection of recyclable paper waste of Istanbul's hotels is explained below:

First stage: Environmental benefits to be gained by source-separated collection of 1 ton of recyclable waste paper were examined and it was decided to employ Kinsella (2012) for the study (Table 5).

Table 5. Environmental Benefits of Using Recycled Copy Paper Rather than Virgin Copy Paper (Kinsella 2012)

\begin{tabular}{|c|c|c|c|}
\hline & $\begin{array}{c}1 \text { ton virgin } \\
\text { fiber paper }\end{array}$ & $\begin{array}{c}1 \text { ton } \\
100 \% \text { recycled paper }\end{array}$ & $\begin{array}{c}\text { Environmental saving } \\
\text { from recyled content }\end{array}$ \\
\hline Trees & 24 trees & 0 trees & $100 \%$ \\
\hline Energy & 33 million BTUs & 22 million BTUs & $33 \%$ \\
\hline $\begin{array}{c}\text { Greenhouse gases } \\
\text { released-CO } 2, \text { equivalent }\end{array}$ & 5,601 pounds & 3,533 pounds & $37 \%$ \\
\hline Waste water & 22,853 gallons & 11,635 gallons & $49 \%$ \\
\hline Solid waste & 1,922 pounds & 1,171 pounds & $39 \%$ \\
\hline
\end{tabular}

Source: Kinsella (2012). 
Amounts of environmental benefits to be gained by source-separated collection of 1 ton of recyclable waste paper as given in Table 5 were converted into metric system measurement units (Table 6).

Table 6. Environmental Benefits Obtained by Recycling of 1 Tons of Paper Waste (Kinsella 2012)

\begin{tabular}{|c|c|c|c|}
\hline \multirow{2}{*}{ Types of Benefits } & \multirow{2}{*}{1 ton virgin fiber paper } & \multicolumn{2}{|c|}{$\begin{array}{c}1 \text { ton } 100 \% \text { recycled paper } \\
\text { environmental saving from recyled content }\end{array}$} \\
\cline { 3 - 4 } & & Percent \% & Amount \\
\hline Trees & 24 trees & $100 \%$ & 24 trees \\
\hline Energy & $9671,35 \mathrm{kwh}$ & $33 \%$ & $6,448 \mathrm{kwh}$ \\
\hline $\begin{array}{c}\text { Greenhouse gases } \\
\text { released-CO2, equivalent }\end{array}$ & 2.541 ton & $37 \%$ & 1.603 ton \\
\hline Waste water & $86,508 \mathrm{Litre}$ & $49 \%$ & 44,043 ton \\
\hline Solid waste & 0.872 ton & $39 \%$ & 0.5 ton \\
\hline
\end{tabular}

Source: Kinsella (2012).

In conclusion, in this study, the amounts of environmental benefits arising from separate collection of 1 ton waste paper by using Table 6 and the literature are given below;

$P_{1}$ : trees not cut, 24 trees,

$P_{2}$ : electricity saved, $6,448 \mathrm{kwh}$,

$P_{3}$ : saved water, 4.40 ton,

$P_{4}: \mathrm{CO}_{2}$ not emitted to the atmosphere: 1.6 ton,

$P_{5}$ : Saved solid waste storage area $2 \mathrm{~m}^{3}$,

$P_{6}$ : revenues obtained from $4.2 \mathrm{~m}^{2}$ forestry area saved from destruction,

$P^{7}$ : The amount of scrap paper, 1 ton,

(AGED 2017; Yorulmaz 2014; Öztürk 2013; Kinsella 2012; Ertürk and Görgün 2011; Y1ldıbbaş 2007).

Second stage: The monetary values of 7 environmental benefits specified in the first stage were determined as below:

- $\quad P_{1}$ : Average value of a coniferous pine tree that can be used for paper production was 186.13 Turkish Liras (TRY) (61.57 United States Dollar (US\$)) (TR Ministry of Forests and Water Affairs 2016; TR Central Bank of Turkey 2016)

- $\quad P_{2}$ : Price of electricity was 0.34 TRY (0.113 US\$) per kWh (TEDAS 2016; Energy World Magazine 2016).

- $\quad P_{3}$ : Price of water was 9.32 TRY (3.08 US\$) per ton (İSKİ 2016)

- $P_{4}$ : Cost of prevention of atmospheric dispersion of $\mathrm{CO}_{2}$ was $194.50 \mathrm{TRY}$ (64.34 US\$) per ton (TR Ministry of Energy and Natural Resources 2016)

- $P_{5}$ : Cost of waste landfill area was 7.40 TRY (2.450 US\$) per $\mathrm{m}^{3}$ (Güllü 2006)

- $\quad P_{6}$ : Annual gain of pine forests was 0.42 TRY (0.14 US\$) per $\mathrm{m}^{2}$ (Bekiroğlu 2002)

- $\quad P_{7}$ : Waste paper scrap value was 324.15 TRY (107.23 US\$) per ton (Ayhan Metal Recycling Industry Limited Company 2016).

It was not possible to obtain 2015 data for values of some of the benefits listed above (for instance $P_{1}, P_{6}$ ). In this case price indexes were used (TSI 2017).

Third stage: Considering the number of rooms, recyclable waste paper capacities of the hotels in Istanbul have been determined. For this calculation, values given in the Table 6 and also in Banar's study (2015), which is still applicable for Turkey-Istanbul. Banar (2015) states "a hotel with 100 rooms can collect up to 50 thousand packaging boxes 
thus contributing 1 ton of waste paper to the economy". Based on this information, it was assumed that a hotel room can produce an average of $0.01 \mathrm{~kg}$ of recyclable waste paper. Approximate amounts of recyclable waste paper contribution of Istanbul's hotels are given in the Table 7 (in 2015).

Table 7. Amount of Assessable Waste Paper Collected in Istanbul's Hotels

\begin{tabular}{|c|c|c|c|c|c|}
\hline \multicolumn{3}{|c|}{ European Side } & \multicolumn{3}{c|}{ Anatolian Side } \\
\hline District & $\begin{array}{c}\text { Number of } \\
\text { Rooms }\end{array}$ & $\begin{array}{c}\text { Recyled waste } \\
\text { paper (tons) }\end{array}$ & District & $\begin{array}{c}\text { Number of } \\
\text { Rooms }\end{array}$ & $\begin{array}{c}\text { Recyled waste } \\
\text { paper (ton) }\end{array}$ \\
\hline Fatih & 19,821 & 198 & Pendik & 4,054 & 41 \\
\hline Beyoğlu & 11,412 & 114 & Kadıköy & 3,604 & 36 \\
\hline Şişli & 8,409 & 84 & Ataşehir & 1,952 & 20 \\
\hline Beşiktaş & 5,406 & 54 & Üsküdar & 1,352 & 14 \\
\hline Bakırköy & 3,003 & 30 & Beykoz & 1,051 & 11 \\
\hline Others & 12,012 & 120 & Maltepe & 901 & 9 \\
\hline \multicolumn{5}{|c|}{ Overall: 752 tons } \\
\hline Total & 60,063 & Others & 2,102 & 21 \\
\hline \multicolumn{7}{|c|}{600} & Total & 15,016 & 152 \\
\hline
\end{tabular}

As shown in Table 7, for 2015, a total amount of 750.8 tons of waste paper could have been obtained from hotels in Istanbul. Eighty percent of this figure was generated by the hotels in the European side of the city.

Fourth stage: In this stage estimated values of environmental benefits $\left(Q_{j}\right)$ created by the recyclable waste paper collected from Istanbul's hotels in the year 2015 (Table 8) by use of Tables 6 and 7.

Table 8. Amounts of the Benefits of Recycling Waste Paper Obtained from Hotels in Istanbul by District (2015)

\begin{tabular}{|c|c|c|c|c|c|c|c|c|}
\hline & District & $\begin{array}{c}Q_{1} \\
\text { Trees } \\
\text { (Number) }\end{array}$ & $\begin{array}{c}Q_{2} \\
\text { Electricity } \\
(\mathrm{kWh})\end{array}$ & $\begin{array}{c}Q_{3} \\
\text { Water } \\
\text { (ton) }\end{array}$ & $\begin{array}{l}Q_{4} \\
\mathrm{CO}_{2} \\
\text { ton) }\end{array}$ & $\begin{array}{c}Q_{5} \\
\text { Landfill } \\
\text { area }\left(\mathrm{m}^{3}\right)\end{array}$ & $\begin{array}{c}Q_{6} \\
\text { Forestry } \\
\text { Area }\left(\mathrm{m}^{2}\right) \\
\end{array}$ & $\begin{array}{c}Q_{7} \\
\text { Scrap } \\
\text { Paper(ton) }\end{array}$ \\
\hline \multirow{7}{*}{ 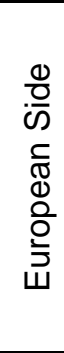 } & Fatih & 4,757 & $1,278,058$ & 872 & 317 & 396 & 8,424 & \begin{tabular}{|l|}
198 \\
\end{tabular} \\
\hline & Beyoğlu & 2,739 & 735,846 & 502 & 183 & 228 & 4,850 & 114 \\
\hline & Şişli & 2,018 & 542,212 & 370 & 135 & 169 & 3,574 & 84 \\
\hline & Beşiktaş & 1297 & 348,579 & 238 & 87 & 108 & 2,298 & 54 \\
\hline & Bakırköy & 721 & 193,633 & 132 & 48 & 60 & 1,276 & 30 \\
\hline & Others & 2,883 & 774,534 & 529 & 192 & 240 & 5,105 & 120 \\
\hline & Total & 14,415 & $3,872,862$ & 2,643 & 962 & 1201 & 25,527 & 600 \\
\hline \multirow{8}{*}{ 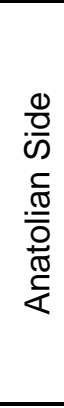 } & Pendik & 973 & 261,402 & 178 & 65 & 81 & 1,723 & 41 \\
\hline & Kadıköy & 865 & 232,386 & 159 & 58 & 72 & 1,532 & 36 \\
\hline & Ataşehir & 468 & 125,865 & 86 & 31 & 39 & 830 & 20 \\
\hline & Üsküdar & 325 & 87,177 & 60 & 22 & 27 & 575 & 14 \\
\hline & Beykoz & 252 & 67,769 & 46 & 17 & 21 & 447 & 11 \\
\hline & Maltepe & 216 & 58,097 & 40 & 14 & 18 & 383 & 9 \\
\hline & Others & 505 & 135,537 & 93 & 34 & 42 & 893 & 21 \\
\hline & Total & 3,604 & 968,233 & 662 & 241 & 300 & 6,383 & 152 \\
\hline \multicolumn{2}{|c|}{ Overall } & 18,019 & $4,841,095$ & 3,305 & 1,203 & 1,501 & 31,910 & 752 \\
\hline
\end{tabular}


Fifth stage: In the last stage, the total economic value of the environmental benefits created by the Istanbul hotels' collection of recyclable waste papers and delivery of them to the authorized units was calculated as follows:

$$
T E V=\Sigma P_{i} \times Q_{j}
$$

where $P_{i}$ indicates the unit economic value (US\$) of benefit $i$. (see: second stage), and $Q_{j}$ indicates the amount of benefit $j$. (see: Table 8).

\section{RESULTS AND DISCUSSION}

\section{Descriptive Characteristics of Study Variables}

\section{General environmental management}

The percentage distribution for the variables of the General Environmental Management group are given in Fig. 5.

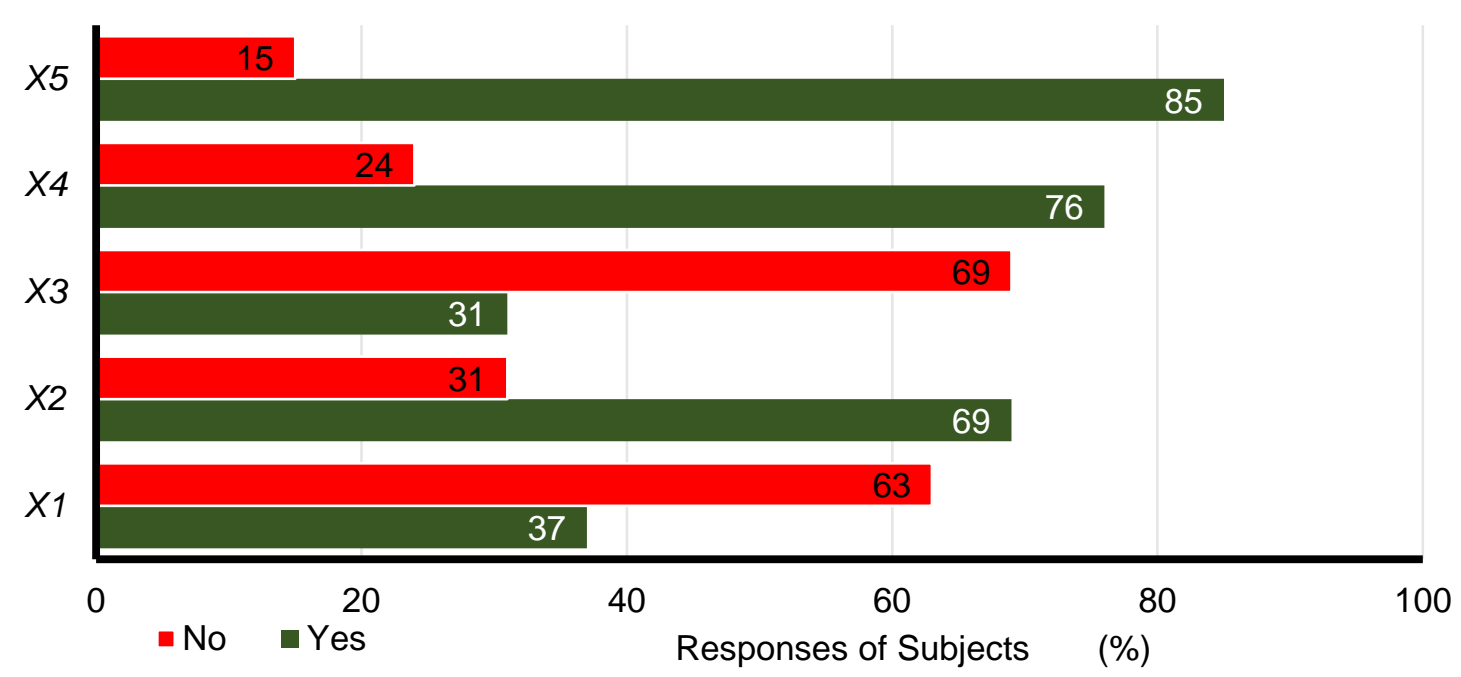

Fig. 5. General environmental management variables percentage distribution

As shown in Fig. 5, in Istanbul's hotels, over $75 \%$ of the participants stated that they have adopted an environmentally-sensitive service approach and environmental policy, and they preferred environmentally-friendly products (X4 and X5). More than 60\% of the participants stated that they do not have a system in place to measure their environmental performances and do not participate in a green environment program $(X 1$, $X 2, X 3)$. For this reason, it is understood that Istanbul's starred hotels attach importance to environmental management but sustainable tourism is yet to be adopted as a priotized strategic target. In TUROB (2013b) regarding certification environmental sustainability, Istanbul's 5-star hotels' level is "medium (3 points score) (excellent, 5 points; very weak, 1 point). However, as the number of stars reduces, so does the level. In this research, it is stated that star hotels in Istanbul are in general poor level of sustainability certification status which corresponds to the findings of the Fig. 5. 


\section{Personnel responsibilities}

Figure 6 shows the percentage distribution of the results of the variables from the Personnel Responsibilities group.

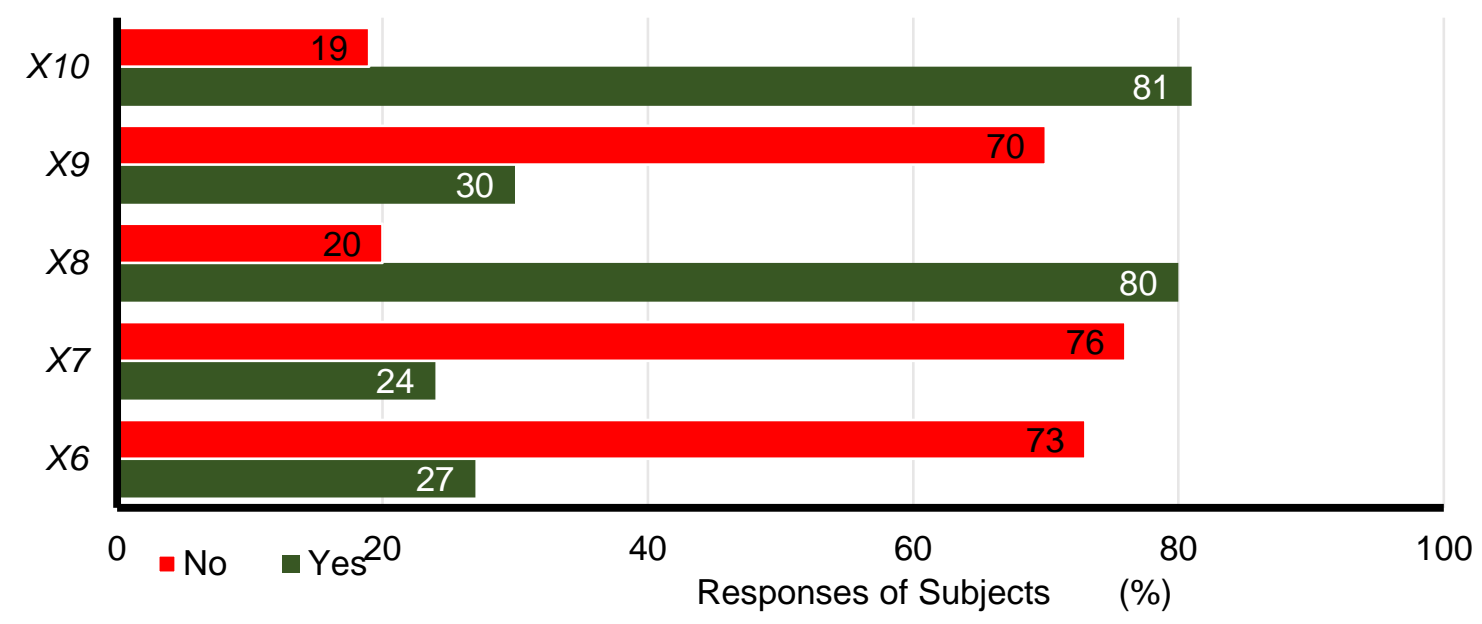

Fig. 6. Personnel responsibilities variables percentage distribution

Figure 6 indicates that $80 \%$ of the participants preferred to employ environmentally friendly personnel $(X 7)$. In contrast, $70 \%$ of participants admitted that they do not have a set of criteria to evaluate environmentally sensitive personnel (X9), 73\% stated they do not have an environment coordinator $(X \sigma)$, and $76 \%$ stated that the existing hotel staff did not receive any training related to environmental protection $(X 7)$.

TUROB (2013b) points that Istanbul's Hotels prefer most the "Greening Hotel" certificate among various sustainability and environmental protection certificates such as "Greening Hotel", "Leed Certificate1, "GRI Reporting Principles", "Green Star", "ISO 14001 " and "ISO 26000 Social Responsibility" and that overall interest in certification is rather low and states that lack of interest by these hotels, which in fact host high numbers of foreign tourists in certificates that support sustainability is actually surprisingly. Moreover, in staff recruitment, the hotels attach $44 \%$ importance to expertise in environmental management and $20 \%$ in expertise in sustainability. These results support the conclusions given in Fig. 6.

\section{Energy and natural resources savings}

The percentage distribution of the responses to the variables in the Energy and Natural Resources Savings group are given in Fig. 7.

As shown in Fig. 7, 53\% of the participants stated that they do not pioneer in water and electricity related subjects (X20). However, $70 \%$ to $100 \%$ of the participants also stated that they take necessary precautions regarding water and energy savings (X16). According to these results, it is seen that Istanbul's hotels are rather enthusiastic to take measures to reduce water and energy consumption. It is considered that this interest is caused by the rapid decreases in operation costs upon energy and water saving. A similar conclusion is reached in TUROB (2013b). 


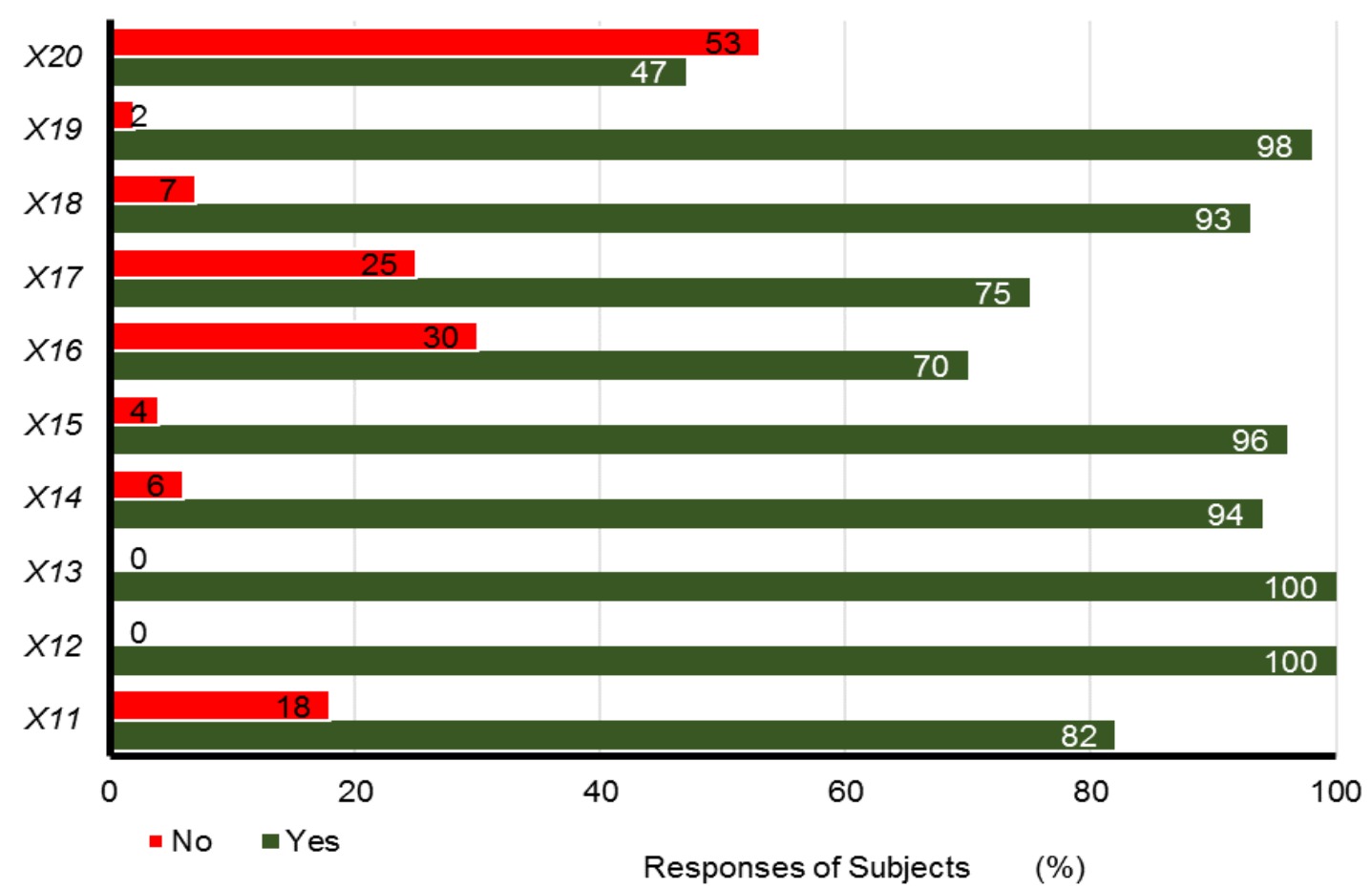

Fig. 7. Energy and natural resources savings variables percentage distribution

Solid waste and waste paper recycling

The percentage distribution of responses to the variables in the Solid Waste and Waste Paper Recycling group are given in Fig. 8.

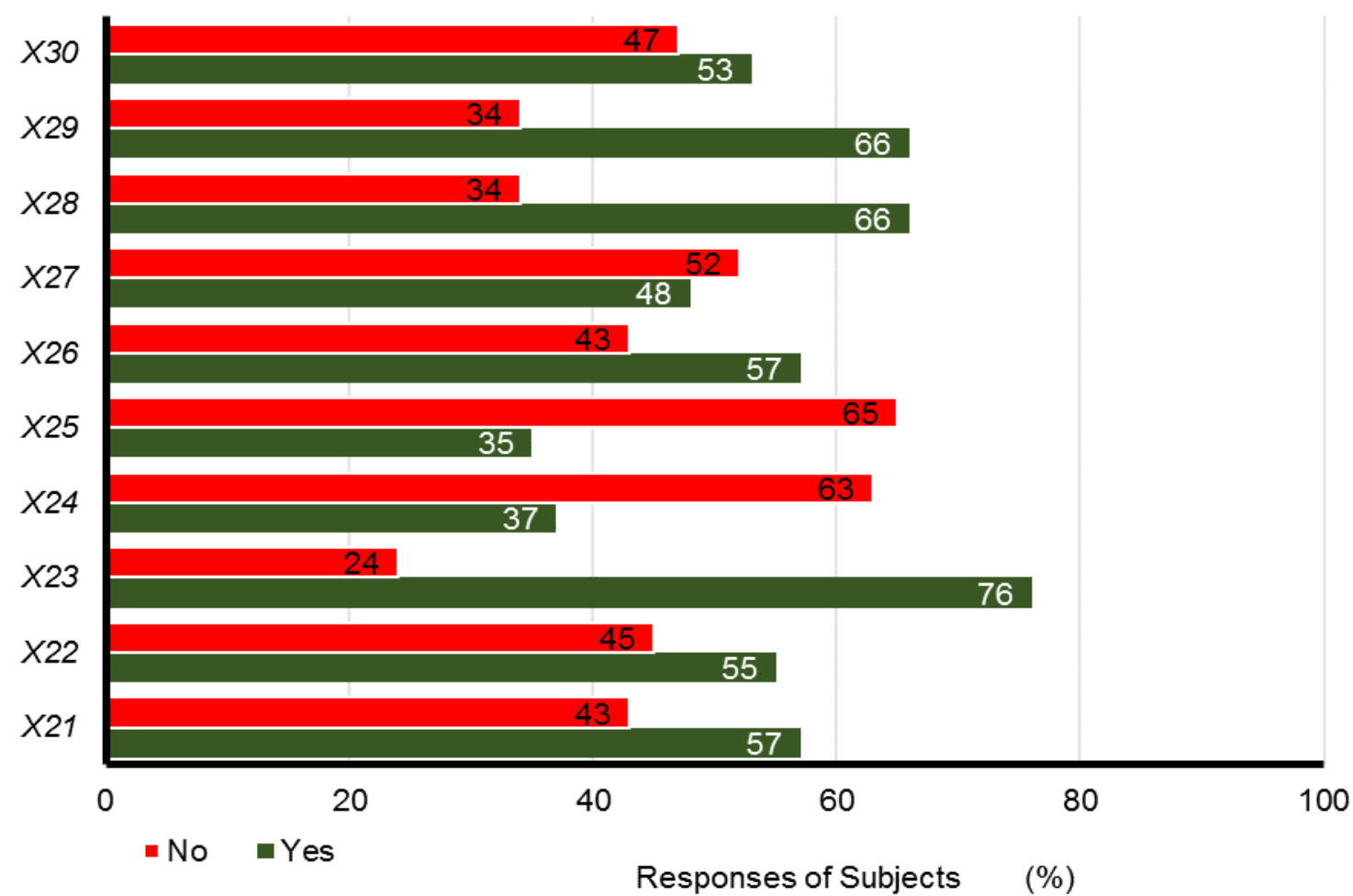

Fig. 8. Solid waste and waste paper recycling variables percentage distribution) 
Figure 8 shows that, among the participants, $76 \%$ stated they place recycling bins at various points in the hotels $(X 23), 63 \%$ stated that they do not process the legally obligatory waste $(X 24)$, and $65 \%$ stated that they do not use recycled paper products $(X 25)$. In contrast, 52\% stated that the recycling bins do not attract attention of the clients $(X 27)$, and $66 \%$ said they periodically deliver paper waste to solid waste collection centers $(X 28)$. These results indicate that the level of sensibility and/or awareness towards recycling of recyclable solid waste is rather good. However, this high level can be a result of legal obligations rather than volunteer action because two options under environmentalism and sustainable natural resource management as "Complying with legal obligations to process relevant waste" and "Use of recycled paper products" were approved with a ratio less than $40 \%$. According to TUROB (2013b) the hotels in Istanbul are not willing to perform activities related to environmental conservation and sustainability, but this situation can change with the increase of environmentalist tourists and pressures on the tourism sector. $\mathrm{H}_{1}$

\section{Knowledge of recycling paper waste}

Fifty percent of the study participants stated that they dump paper waste in the proper recycling bins (X31). Moreover, $80 \%$ of the participants were aware that paper waste accounts for more than half of the total recyclable solid waste (X32). However, 70\% did not know about the multitude of benefits obtained from recycling paper waste (X33). Various studies conducted in different neighborhoods of Istanbul showed similar results concerning the level of knowledge and awareness of environmental pollution, forestry preservation, and recycling. These results indicate that sensibility of Istanbul's hotels towards environmental protection and sustainable management of natural resources is not as developped as necessary. TUROB (2013b) provides similar results.

\section{Results of the Chi-square Test of Independence}

The chi-square test of independence is a non-parametrical relationship analysis technique. The results of the chi-square test conducted within the framework of this study are given in Table 9. For the analysis, a $2 \times 2$ Crosstab and degree of freedom (df) of 1 were used. The hypotheses were tested according to the Yates' chi-square test continuity correction values. At a significance level of 5\%, if the Asymp. Sig. (p) of the continuity correction value was $<0.05$, then the hypothesis $\mathrm{H}_{\mathrm{a}}$ was assumed. If it was $>0.05$, then the hypothesis $\mathrm{H}_{0}$ was assumed.

Upon examination of the results given in Table 9, it was determined that the Asymp. Sig. (2-sided) (p) values in the highlighted cells were <0.05. Therefore, it was assumed that there was a relationship among the variables of those cells (Hypothesis $\mathrm{H}_{\mathrm{a}}$ accepted). Consequently, Table 9 showed a statistically significant correlation between: 1 - The variables $X 1, X 2, X 3, X 4, X 5, X 6$, and $X 8$, and the variables $X 28$ and $X 29,2$-The variables $X 1, X 2, X 3, X 4, X 7, X 8$, and $X 9$, and the variable $X 25$, and 3 -The variables $X 3$ and $X 6$, and the variable $X 30$. 
Table 9. Results of the Chi-square Test

\begin{tabular}{|c|c|c|c|c|c|c|c|c|c|c|c|c|c|c|c|c|c|c|c|c|c|}
\hline & & $X 10$ & $X 11$ & $X 14$ & $X 15$ & $X 16$ & $X 17$ & $X 18$ & $X 19$ & $X 20$ & $X 21$ & $x 22$ & $X 23$ & $X 24$ & $X 25$ & $X 26$ & $X 27$ & $X 28$ & $X 29$ & $X 30$ & $X 31$ \\
\hline \multirow[t]{2}{*}{$X 1$} & $\begin{array}{c}\chi^{2} \\
\text { value }^{a}\end{array}$ & 65 & 1.36 & .39 & .00 & 2.65 & .70 & 2.87 & .13 & .00 & 15.5 & 11.51 & 6.81 & .60 & 3.90 & 7.19 & 7.81 & 9.58 & 9.58 & 1.44 & 8.4 \\
\hline & $\mathrm{p}^{\mathrm{b}}$ & .42 & 8 & 53 & .98 & .10 & .40 & .09 & .72 & 1.00 & $.00^{c}$ & $.00^{c}$ & $01^{c}$ & .44 & $048^{c}$ & $01^{c}$ & $.005^{c}$ & $.00^{\mathrm{c}}$ & $.00^{c}$ & .23 & $00^{\circ}$ \\
\hline \multirow[t]{2}{*}{$X 2$} & $\begin{array}{c}\chi^{2} \\
\text { value }\end{array}$ & .45 & 5.17 & .23 & .00 & 11.5 & 3.51 & .08 & .03 & 1.67 & 33.08 & 25.2 & 12.8 & .21 & 11.10 & 28.3 & .027 & 34.99 & 34.99 & .16 & 15.1 \\
\hline & $\mathrm{p}$ & $01^{c}$ & 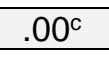 & 11 & 1.00 & $.00^{c}$ & .06 & .78 & .85 & .20 & .00 & $.00^{c}$ & $.00^{c}$ & .65 & $.00^{c}$ & $.00^{c}$ & .87 & $.00^{\circ}$ & 0 & .29 & $00^{\circ}$ \\
\hline \multirow[t]{2}{*}{$X 3$} & $\begin{array}{c}\chi^{2} \\
\text { value }\end{array}$ & .49 & 5.27 & .00 & .08 & .721 & .39 & .00 & .00 & .00 & 6.48 & 7.86 & .23 & .00 & 6.56 & 8.9 & 1.28 & 5.29 & 5.29 & 4.82 & 2.9 \\
\hline & $p$ & .06 & $.02^{\mathrm{c}}$ & .00 & .77 & .40 & .53 & 1.00 & 1.00 & .98 & .01 & . & .63 & .99 & .01 & 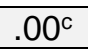 & .26 & $.0 L$ & $.02^{\mathrm{c}}$ & $.03^{\mathrm{c}}$ & .08 \\
\hline \multirow[t]{2}{*}{$X 4$} & $\begin{array}{c}\chi^{2} \\
\text { value }\end{array}$ & .53 & 6.49 & 9.10 & .00 & 7.33 & 8.85 & .57 & .00 & 2.28 & 11.53 & 7.20 & 9.90 & 5.02 & 5.79 & 8.54 & .211 & 21.31 & 21.31 & .13 & 9.3 \\
\hline & $p$ & $.02^{\mathrm{c}}$ & & $.00^{c}$ & 1.00 & $01 \mathrm{c}$ & $.00^{c}$ & .45 & 1.00 & .13 & $0 \Omega c$ & $01 \mathrm{c}$ & $.00^{c}$ & $.03^{c}$ & $016^{c}$ & $.00^{\mathrm{c}}$ & .65 & $.00^{c}$ & $.00^{c}$ & .71 & $.00^{c}$ \\
\hline \multirow[t]{2}{*}{$x 5$} & $\begin{array}{c}\chi^{2} \\
\text { value }\end{array}$ & .39 & 4.16 & 3.56 & .020 & 1.49 & 1.28 & .24 & .00 & .06 & 5.25 & 2.4 & 1.55 & .00 & 1.06 & d & .03 & 6.77 & 6.76 & .06 & 1.3 \\
\hline & $p$ & .24 & $.04^{c}$ & .059 & .89 & .22 & .26 & .62 & 1.00 & .80 & $02 c$ & 12 & .21 & 1.00 & .30 & $d$ & 87 & $01 \mathrm{C}$ & $.01^{\mathrm{c}}$ & .80 & .26 \\
\hline \multirow[t]{2}{*}{$X 6$} & $\begin{array}{c}\chi^{2} \\
\text { value }\end{array}$ & .00 & .00 & .00 & 2.7 & .47 & C & 2.02 & .00 & 6.88 & 17.18 & 15.34 & 4.41 & 12.28 & .25 & .25 & 11.56 & 17.03 & 17.04 & 7.80 & .00 \\
\hline & $p$ & .00 & .00 & 1.00 & .103 & .49 & c & .16 & 1.00 & $.01^{\mathrm{c}}$ & $.00^{\circ}$ & $.00^{c}$ & $.04^{\mathrm{c}}$ & $.00^{\circ}$ & .62 & .61 & $.00^{\circ}$ & $.00^{c}$ & $.00^{\mathrm{c}}$ & $.01^{\mathrm{c}}$ & 1.00 \\
\hline \multirow{2}{*}{$X 7$} & $\begin{array}{c}\chi^{2} \\
\text { value } \\
\end{array}$ & 5.87 & 5.42 & .00 & .30 & .75 & .07 & .56 & .00 & 0.00 & 3.26 & 4.06 & .48 & .62 & 4.05 & 5.19 & .00 & 3.27 & 3.27 & .00 & 1.4 \\
\hline & (p) & & $.02^{\mathrm{c}}$ & .95 & .58 & .38 & .79 & .45 & .00 & 1.00 & 07 & 0 & .49 & .432 & $.04^{c}$ & $.02^{\mathrm{c}}$ & .99 & .07 & .07 & 1.00 & 24 \\
\hline \multirow[t]{2}{*}{$X 8$} & $\begin{array}{c}\chi^{2} \\
\text { value }\end{array}$ & $\begin{array}{c}18.2 \\
3 \\
\end{array}$ & 3.56 & .10 & .80 & .67 & .75 & .00 & .032 & .00 & 8.88 & 5.11 & .99 & .69 & 5.56 & 8.88 & .00 & 9.05 & 9.05 & 1.11 & 5.1 \\
\hline & $(p)$ & $.00^{\mathrm{c}}$ & .06 & .75 & .39 & .41 & .39 & 1.00 & .86 & .96 & $.00^{c}$ & $.02^{\mathrm{c}}$ & .32 & .57 & $.02^{\mathrm{c}}$ & $.00^{c}$ & 1.00 & $.00^{c}$ & $.01^{\mathrm{c}}$ & .29 & $.02^{c}$ \\
\hline \multirow[t]{2}{*}{$x 9$} & $\begin{array}{c}\chi^{2} \\
\text { value }\end{array}$ & 1.49 & 7.75 & .08 & .00 & 9.58 & 1.02 & 1.87 & .00 & .49 & 3.76 & 3.08 & .00 & .00 & 7.53 & 2.25 & .15 & 2.91 & 2.91 & $.00^{c}$ & 5.8 \\
\hline & $p$ & .22 & $.01^{\mathrm{c}}$ & .78 & 1.00 & $.00^{c}$ & .31 & .17 & 1.00 & .48 & .05 & .08 & 1.00 & 1.00 & $.01^{\mathrm{c}}$ & .13 & .69 & .09 & .09 & 1.00 & $02^{\mathrm{c}}$ \\
\hline
\end{tabular}

a. Computed only for a $2 \times 2$ table; Yates' chi-square (Continuity correction) value

b. p: Asymp. Sig. (2-sided)

c. Because $\mathrm{p}<0.05 \%$, then $\mathrm{H}_{\mathrm{a}}$ : Variables are not independent from each other (relationship among the variables)

d. Not assuming the null hypothesis 
According to these results, it is accepted, with a confidence level of 95\%, that if the managers in Istanbul's hotels are sensitive to the environment and to sustainable natural resource management, and if they are qualified enough to test the environmental and protective tendency of their staff, then it is assumed that these hotels have environmental protection policies in place and they will support their personnel's training in environmental protection and they will collect the waste paper separated at source. However, this assumption only applies to starred hotels because smaller hotels have no sensibility towards environmental protection and sustainable tourism. It was determined that the larger hotels, especially those members of a chain attach more importance to sustainability (Zhang et al. 2008).

\section{Economic Contribution of Recycling Waste Paper Generated in Istanbul Hotels}

This section calculated the monetary equivalent of the seven benefits from recyclable waste paper, and that of the seven environmental benefits created by the total amount of waste paper assumed to be delivered to recycling facilities by Istanbul hotels in 2015.

The economic values of the benefits of recycling waste paper from hotels in Istanbul are given in Table 10 by district (by 2015).

Table 10. Economic Values of the Benefits of Recycling Waste Paper $\left(P_{i} \times Q_{j}\right)$ from Hotels in Istanbul by District (2015)

\begin{tabular}{|c|c|c|c|c|c|c|c|c|c|}
\hline & District & $\begin{array}{r}P_{1} \times Q_{1} \\
(U S \$)\end{array}$ & $\begin{array}{r}P_{2 \times Q_{2}} \\
(U S \$)\end{array}$ & $\begin{array}{l}P_{3 \times Q_{3}} \\
\text { (US\$) }\end{array}$ & $\begin{array}{l}\mathrm{P}_{4 \times \mathrm{Q}_{4}} \\
\text { (US\$) }\end{array}$ & $\begin{array}{l}P_{5} \times Q_{5} \\
\text { (US\$) }\end{array}$ & $\begin{array}{l}P_{6 \times Q_{6}} \\
\text { (US\$) }\end{array}$ & $\begin{array}{l}P_{7 \times Q_{7}} \\
\text { (US\$) }\end{array}$ & $\begin{array}{c}\text { TEV } \\
\Sigma \mathrm{Pi} \times \mathrm{Qi}\end{array}$ \\
\hline \multirow{7}{*}{ 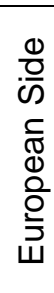 } & Fatih & 271,530 & 127,806 & 2,485 & 18,820 & 1,782 & 1,179 & 19,590 & 164,246 \\
\hline & Beyoğlu & 156,342 & 73,585 & 1,431 & 10,865 & 1,026 & 679 & 11,279 & 255,207 \\
\hline & Şişli & 115,187 & 54,221 & 1,055 & 8,015 & 761 & 500 & 8,311 & 188,050 \\
\hline & Beşiktaş & 74,033 & 34,858 & 678 & 5,165 & 486 & 322 & 5,343 & 120,885 \\
\hline & Bakırköy & 41,155 & 19,363 & 376 & 2,850 & 270 & 179 & 2,968 & 64,596 \\
\hline & Others & 164,562 & 77,453 & 1,508 & 11,399 & 1,080 & 715 & 11,873 & 267,618 \\
\hline & Total & 822,808 & 387,286 & 7,533 & 57,114 & 5,405 & 3,574 & 59,364 & $1,060,602$ \\
\hline \multirow{9}{*}{ 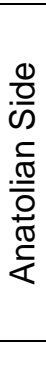 } & Pendik & 55,539 & 26,140 & 507 & 3,859 & 365 & 241 & 4,057 & 67,182 \\
\hline & Kadıköy & 49,374 & 23,239 & 453 & 3443 & 324 & 214 & 3,562 & 80,609 \\
\hline & Ataşehir & 26,713 & 12,587 & 245 & 1,840 & 176 & 116 & 1979 & 42,000 \\
\hline & Üsküdar & 18,551 & 8,718 & 171 & 1,306 & 122 & 81 & 1,385 & 30,334 \\
\hline & Beykoz & 14,384 & 6,777 & 131 & 1,009 & 95 & 63 & 1,088 & 23,547 \\
\hline & Maltepe & 12,329 & 5,810 & 114 & 831 & 81 & 54 & 890 & 14,880 \\
\hline & Others & 28,825 & 13,554 & 265 & 2,019 & 189 & 125 & 2,078 & 47,055 \\
\hline & Total & 205,716 & 96,823 & 1,887 & 14,308 & 1,350 & 894 & 15,039 & 305,607 \\
\hline & Overall & $1,028,525$ & 484,110 & 9,419 & 71,422 & 6,755 & 4,467 & 74,403 & $1,366,209$ \\
\hline
\end{tabular}

The distribution by district of the economic benefits of hotels that contributed to waste paper recycling in Istanbul is given in Table 11. 
Table 11. Total Economic Value of the Contribution to Waste Paper Recycling in Istanbul by District (2015)

\begin{tabular}{|c|c|c|c|c|c|}
\hline \multicolumn{3}{|c|}{ European Side } & \multicolumn{3}{c|}{ Anatolian Side } \\
\hline District & $\begin{array}{c}\text { Waste } \\
\text { Paper } \\
\text { (ton) }\end{array}$ & $\begin{array}{c}\text { TEV } \\
\text { (US\$) }\end{array}$ & District & $\begin{array}{c}\text { Waste Paper } \\
\text { (ton) }\end{array}$ & $\begin{array}{c}\text { TEV } \\
\text { (US\$) }\end{array}$ \\
\hline Fatih & 198 & 164,246 & Pendik & 41 & 67,182 \\
\hline Beyoğlu & 114 & 255,207 & Kadıköy & 36 & 80,609 \\
\hline Şişli & 84 & 188,050 & Ataşehir & 19 & 42,000 \\
\hline Beşiktaş & 54 & 120,885 & Üsküdar & 14 & 30,334 \\
\hline Bakırköy & 30 & 64,596 & Beykoz & 10 & 23,547 \\
\hline Others & 12 & 267,618 & Maltepe & 9 & 14,880 \\
\hline & & & Others & 21 & 47,055 \\
\hline Total & 600 & $1,060,602$ & Total & 150 & 305,607 \\
\hline \multicolumn{7}{|c|}{ Overall TEV $=1,366,209$ US\$ } \\
\hline
\end{tabular}

Table 11 indicates that the contribution from the European side to this figure was 1,060,602 US\$, while the Anatolian side contributed 305,607 US\$. There was a total amount of 1,366,209 US\$ for Istanbul in 2015. The natural resources of European Side has been destroyed to a degree much higher than the Anatolian Side due to various reasons such as residence, industry, commerce, transportation (airports, motorways) and tourism (Karakaya 2008). The fact that European Side's hotels contribute 4 times more than Anatolian Side can be accepted as a small compensation for this destruction.

Assuming that recyclable waste paper is recycled an average of 5 times in a year, the monetary equivalance of environmental benefits obtained reaches 6.8 million US dollars. The 6.8 million worth of environmental benefits created by Istanbul's Hotels, corresponds $1.6 \%$ of Istanbul Metropolitan Municipality's 2015 budget (US\$ 422.4 million) (IBB 2015). On the other hand, this figure corresponds $78 \%$ of Turkey's paper and paper products sector's average foreign trade deficit in last five years (Çevik 2016).

$86 \%$ of Turkey's lands are under threat of erosion and half of the forestry lands, that cover $22 \%$ of country are damaged. For this reason, TR Ministry of Forests and Water Affairs attach great importance to forestation activities and provides incentives to those who wish to privately conduct forestation activities up to 3300-3700 US\$ (TR Ministry of Forest and Water Affairs 2017). With the figures explained above, Istanbul's hotels can provide support for 390 hectares of forestation on average per year.

It is known that sustainability-related activities of hoteling sector are affected by motivation and moral values. For this reason, knowledge about the magnitude of positive impact of environment-friendly activities would be a motivating factor for this sector.

Starting from 1960s economic development plans have been prepared and implemented in Turkey. These plans are prepared for 5 years' periods and define objectives to strengthen the sectors. Concerning advancement of waste recycling, the $10^{\text {th }}$ Development Plan which belongs to the period of 2014-2018 specifies various objectives including; -stressing recycling and re-use practices in industry, - promotion of benefits of recycling as an important dimension of solid waste management, -development of standards of recycled secondary products and, -incentivizing and guidance for recycling. These objectives also indicate that waste recycling does not attract necessary interest in 
Turkey. Nonetheless, inclusion of these objectives in nation-wide development plans indicates that the waste recycling is addressed at national level (TR Ministry of Science, Industry and Technology 2013). The present study determined that despite Istanbul's hotels high $(100 \%)$ sensibility towards measures that reduce the operation costs such as water and electric savings, the interest in sustainable natural resource management such as reintroduction of waste paper into the economy is rather low. This being said, the present study also establishes that the Istanbul's hotels' contribution to recycling efforts would be significant if only 1 tons of waste paper is collected per each 100 rooms.

\section{CONCLUSIONS}

1. Despite limited forest sources, the recycling rate of recyclable waste paper is rather low $(50 \%)$. Nonetheless currently there are many ongoing scientific research and practices to increase the collection of recyclable waste paper by separation at source.

2. An increase in the number of individuals supporting environmental protection and sustainable natural resource management are forcing enterprises to reduce environmental pollution and natural resource destruction they cause.

3. Laws ensure that enterprises undertake environmental management activities to reach normal levels. On the other hand, businesses need motivation to improve environmental management at an advanced level.

4. There was a positive correlation between the financial performance of hotels and their environmental management because of the increased sensitivity and awareness from customers towards environmental subjects.

5. Turkey is one of the top 10 countries that receives highest number of tourists in the world. Being the city that receives highest number of tourists in Turkey (ten million per year) Istanbul has the highest room- and bed-capacity.

6. Population growth, technological development and changing lifestyles rapidly increased the number of people travelling. For this reason, tourism and hoteling, as one of its sub-sectors have been among the fastest growing sectors. These sectors, which are also referred to as smokeless industry, have harmed natural resources, especially forests, which are their actual the capital. For this reason, these two sectors support the conservation of the environment and the sustainable management of natural resources.

7. Seventy percent of managers and employees of hotels in Istanbul adopted an environmentally-sensitive service approach, but the hotels did not have a coordinator for guidance in environmental subjects and lacked knowledge on the benefits of recycling waste paper. However, nearly all of Istanbul hotels took necessary measures for water and energy savings. According to these results, it can be stated that Istanbul's hotels pay attantion to environment-waste management yet they do not engage in sustainable management of natural resources at desirable levels.

8. Recycling of waste paper provides significant contributions to the sustainable management of forestry resources, water and energy sectors, and the environment. For instance, Istanbul's hotels (with 75 thousand total number of rooms), collected and reintroduced to the economy a 752 tons of recyclable waste paper (through seperation at source method) in the year 2015. This figure stands for 18 thousands of trees 
remained uncut and 4.8 million kwh of electricity and 3.3 tons of water saved and 1.2 tons of $\mathrm{CO}_{2}$ emission prevented.

9. Turkey is dependent on foreign sources for paper and paper products sector. For this reason, there is a constant foreign trade deficit in this sector (average foreign trade deficit for the last 5-year's period is 1.8 million US\$). The total estimated economic value of environmental benefits created by source-separated collection of waste paper by hotels in Istanbul is 1.4 million US\$ (only benefits of trees, water, electricity, $\mathrm{CO}_{2}$ and landfill area were considered). This figure corresponds $78 \%$ of foreign trade deficit of Turkey's paper and paper products sector.

10. Consequently, given the problems that concern the supply of raw materials and inputs for paper production in Istanbul hotels, the re-introduction of recycling of paper into the economy would serve as a good means to reduce foreign dependency and environmental pollution, and support the sustainable management of forests and other natural resources.

\section{REFERENCES CITED}

AGED (2017). "Recyclable package," (in Turkish), (AGED: Waste paper recycling association), (https://www.a-ged.org.tr/), accessed 19 May 2017.

Alnıaçık, Ü. (2010). "Environmental tendency, environmentally friendly attitudes and demographical characteristics: a study on university students," (in Turkish), Journal of Socio-Economic Research 20, 507-532.

Altunışık, R., Coşkun, R., Bayraktaroğlu, S., and Yıldırım, E. (2005). Research Methods in Social Sciences, SPSS Application, Fourth Edition, (in Turkish), Sakarya Kitabevi, 360 p. ISBN 975-8644-8-9, Sakarya, Turkey.

Álvarez Gil, M. J., Jiménez, J. B., and Lorente, J. C. (2001). “An analysis of environmental management, organizational context and performance of Spanish hotels," Omega 29(6), 457-471. DOI: 10.1016/S0305-483(01)00033-0.

Armağan, B., Demir, I., Demir, O., and Gök, N. (2006). Evaluation of Solid Waste in Economy, (in Turkish), Istanbul Commerce Chamber, Istanbul, Turkey.

Avfall Sverige (2017). The Swedish Waste Management Association, (http://www.avfallsverige.se/in-english/), accessed 13 April 2017.

Ayhan Metal Recycling Industry Limited Company (2015). "Scrap paper prices," (in Turkish), (https://hurdametalfiyatlari.wordpress.com/category/hurda-kagit-kilosu/), accessed 16 July 2016.

Aykan, E., and Sevim, B. (2013). "Environmental management practices of accommodation establishments and their effects on perceived corporate reputation: a research on hotels of Kayseri and Nevşehir," (in Turkish), Journal of Business Research, 5 (3) 93-113.

Banar, M. (2015). "Importance of recycling and sustainable waste management in hotels," (in Turkish), (http://www.skb.org.tr/otellerde-geri-donusum-surdurulebiliratik-yonetiminin-onemi-s13482k/), accessed 16 July 2016.

Banerjee, S. B. 2002. "Corporate environmentalism the construct and its measurement," Journal of Business Research, 55, 177-191. 
Bekiroğlu, S. (2002). "Investigations on the appraisal of land and forest, a case study: Ayvalik," (in Turkish), Review of the Faculty of Forestry University of Istanbul, Series A, 52(2), 96-123.

Bekiroğlu, S., and Mertoğlu Elmas, G. (2016). "Economic contribution of waste paper recycling (example of Istanbul's hotels)," in: Proceedings of International Forestry Symposium, Kastamonu, Turkey.

Berry, M. A., and Rondinelli, D. A. (1998). "Corporate environmental management: A new industrial revolution," Academy of Management Executive, 12 (2), 38-50.

Butler, R. (1998). "Sustainable tourism-looking backwards in order to progress?," in: Sustainable Tourism: A Geopraphical Perspective, ISBN:0582322626, UK.

Canbay, N. (2011). "Rising trend in tourism sector: Green hotels," (in Turkish), (http://www.yesilbinadergisi.com/?pid=25430), accessed 9 July 2017).

Chan, R.Y. K. (2010). "Corporate environmentalism pursuit by foreign firms competing in China," Journal of World Business 45, 80-92.

Conrad, J. M. (2006). Resources Economics, Cambridge University Press, ISBN 0-52164012-1, 209 p, Cambridge, England

Cunningham, W.P., Cunningham, M.A., and Woodworth Saigo, B. (2003). Environmental Sciences, Seventh Edition, ISBN 0-07-029426-7, McGraw-Hill Companies, United States.

Çevik, B. (2016). "Paper and paper products industry," (https://ekonomi.isbank.com.tr/UserFiles/pdf/sr201607_kagitsektoru.pdf), accessed 13 July 2017.

Çımat, A., and Bahar, O. (2003). "An assessment of tourism sector and its significance in the Turkish economy," (in Turkish), Journal of Akdeniz University Faculty of Economics and Administrative Sciences, (6), 1-18.

Daly, H. E. (1993). "Sustainable growth: An impossobilty theorem," in: Valuing the Earth Economics, Ecology, Ethics, H. E. Daly and K. N. Townsend (eds.), 267-273, The MITT Press, England.

Didin, S., and Köroğlu, Ç. (2008). "The competitiveness of accomodation firms with regard to sales-costs and their future expectations," (in Turkish), ZKÜ Journal of Social Sciences 4 (7), 111-120.

Doğaner Gönel, F. (2002). "In a globalizing world (how) sustainable development," Journal of Birikim, (http://www.birikimdergisi.com/birikim/2348/158), accessed 11 March 2016.

Dönmez, E., and Değirmen, N. (2016). "Comparison of European Union (EU) and waste management practices in Turkey," (in Turkish), in: 3rd International Symposium on Environment and Morality Symposium, 4-6 November 2016, Alanya-Turkey.

Energy World Magazine (2016). "Comparison table of the current fuel price," (www.enerji-dunyasi.com/.../yakit/enerji-dunyasi-101-guncel-yakit-fiyatlarikarsilastir), accessed 9 April 2016.

Ertürk, M. C., and Görgün E. (2011). “An actual example for rehabilitation of open dump areas in Turkey: Rehabilitation of Mersin Çavuşlu open dump area," Journal of Engineering and Natural Sciences 3, 200-208.

European Commission (2012). "Impact Assessment," (http://www.cep.eu/Analysen/COM_2012_710_UAP/Impact_Assessment_SWD_201 2_398.pdf), accessed 11 July 2017.

Faber, M., Manstetten, R., and Proops, J. (1996). Ecological Economics, Concepts and Methods, ISBN 1858982839, Edward Elgar Publishing Ltd, UK. 
Field, B. C., 1994. Environmental Economics an Introduction, McGraw-Hill, Inc., ISBN 0-07-020797-6, USA.

Forumtr (2017). “Turkeys map,” (https://www.frmtr.com/cografya/7039060-turkiyeharitasi-bolgeler.html), accessed 22 May 2017.

Güllü, G. (2006). Cost Analysis of Sanitary Landfill Areas, İSTAÇ A. Ş., Istanbul, Turkey.

Güneş, G. (2011). "The importance of eco-friendly accommodation sector management," (in Turkish), KMÜ Social and Economical Researches Journal 13(20), 45-51.

Holjevac, I. A. (2003). A vision of tourism and the hotel industry in the $21^{\text {st }}$ century, Hospitality Management 22, 129-134

Hubbe, M. A. (2014). "Prospects for maintaining strength of paper and paperboard products while using less forest resources: A review," BioResources 9(1), 1634-1763. DOI: $10.15376 /$ biores.9.1.1634-1763

IBB (2015). "Istanbul Metropolitan Municipality January-March Budget Implementation Results," (IBB: Istanbul Metropolitan Municipality), (http://www.ibb.gov.tr/trTR/kurumsal/Birimler/ButceveDenetimMd/Documents/2015YiliMaliDurum/2015_il k_ceyrek_butce_uyg_sonuc.pdf), accessed 16 May 2016.

ISO (2017). "ISO 14001,"

(https://www.iso.org/files/live/sites/isoorg/files/standards/docs/en/iso_14001_key_benefit s.pdf), accessed 6 June 2016.

İSKİ (2016). "Water tariff in 2016," (İSKİ: Istanbul Water and Sewage Administration (http://www.iski.gov.tr/web/assets/SayfalarDocs/subirimfiyatlari/2013_Su_Birim_ Fiyatlari.pdf), accessed 16 July 2016.

İSTAÇ (2017a). "İSTAÇ A.Ş.," (İSTAÇ: İstanbul Environmental Protection and Waste Material Evaluation Corporation), (http://www.ibb.gov.tr/enUS/Organization/Birimler/IstacAS/Documents/hakkinda.pdf ), accessed 6 June 2017.

İSTAÇ (2017b). “Activity Report 2014," (http://www.ibb.gov.tr/enUS/Organization/Birimler/IstacAS/Documents/hakkinda.pdf), accessed 16 June 2016.

İSTAÇ (2017c). "Strategic Plan (2015-2019)," (http://www.istac.istanbul/contents/15/WEB_ISTAC_STRATEJI.pdf), accessed 6 June 2017.

Karakaya, İ. (2008). "Strategic Municipal Solid Waste Management Approach in Istanbul,” (http://hdl.handle.net/11527/8968), accessed 9 June 2017.

Kasim A., and Scarlat, C. (2007). "Business environmental responsibility in the hospitality industry," Management 1(2), 5-23.

Kinsella, S. (2012). "Paperwork: Comparing recycled to virgin paper: Why Recycled Content is Crucial for Printing \& Writing," (conservatree.org/learn/WhitePaper\%20Why\%20Recycled.pdf), accessed 6 June 2017.

Kollmuss, A., and Agyeman, J. (2002). "Mind the gap: Why do people act environmentally and what are the barriers to proenvironmental behaviour?," Environmental Education Research, 8(3), 239-260.

Kula, E. (1994). Economics of Natural Resources, the Environment and Policies, Chapman \& Hall, London, UK.

Kuvan, Y. (2005). "The use of forests for the purpose of tourism: The case of Belek Tourism Center in Turkey," Journal of Environmental Management, 75 (3), 263-274.

Kuvan, Y. (2010). "Mass tourism development and deforestation in Turkey," An international Journal of Tourism and Hospitality Research 21(1), 155-168. 
Lee, J. Y., Kim, E. H., and Sung, Y. J. (2016). "Improvement in the retention and strength of paper made from white-grade wastepaper," BioResources 11(2), 47184726. DOI: 10.15376.biores.11.2.4718-4726.

Leslie, D. (2007). "The missing component in the 'greening' of tourism: The environmental performance of the self-catering accommodation sector," Hospitality Management, 26, 310-322.

Madan, S., and Rawatu, L. (2000). "The impacts of tourism on the environment of Mussoorie, Garhwal Himalaya, India," The Environmentalist 20, 249-255.

Mertoğlu Elmas, G. (2016). "Potential of waste paper management practices of Istanbul's hotels in sustainability of forests," in: Proceedings of International Forestry Symposium, Kastamonu, Turkey, 964-969.

Micales J. A., and Skog K. E. (1997). "The decomposition of forest products in landfills" International Biodeterioration and Biodegradation 39(2-3), 145-158.

Mrayyan, B., and Hamdi, M. R. (2006). "Management approaches to integrated solid waste in industrialized ones in Jordan: A case of Zarqa City," Waste Manage. 26(2), 195-205.

OECD (2010). "Green Inovation in Tourism,"

(http://cf.cdn.unwto.org/sites/all/files/docpdf/oecdgreeninnovationintourism.pdf), accessed 6 June 2017.

Oktayer, N., Susam, N., and Çak, M. (2007). “Tourism Economy in Turkey,” İstanbul Ticaret Odası Publication No:2007- 69, Istanbul, Turkey.

Özsabuncuoğlu, İ. H., and Uğur, A. A. (2005). Natural Resources Economics, Management and Policy, İmaj Publishing, ISBN 975-8752-31-6, Ankara, Turkey, 525 pp.

Öztürk, M. (2013). "Garbage collection cost can fall down from 50\%," (http://www.haberx.com/cop_toplama_maliyeti_50_dusurulebilir(19,w,12908,959).as px), accessed 16 April 2016.

Pal, L., and Joyce, M. (2017). "Paper need not be flat: Paper and biomaterials industries need to converge to bring about true innovation," BioResources 12(2), 2249-2251. DOI: 10.15376/biores.12.2.2249-2251.

Qui, K. (2017). "Biodiversity and Sustainable Tourism: The Pillar of Island Economies," (https://www.cbd.int/idb/image/2017/briefs/idb-2017-press-brief-islandeconomies.pdf), accessed 8 June 2017.

Saatcı, G., Güdü Demirbulat, Ö., and Avcıkurt, C. (2013). "Green innovation applications in accommodation enterprises: Bursa example,"14. National Tourism Congress, 0508 December 2013, Kayseri.

SBA (2008). "Best environmental practices for the hotel industry," Sustainable Business Associates, (http://www.sbaint.ch/spec/sba/download/BGH/SBABGEHOTELLERIEENG2008.pdf), accessed 16 April 2016.

Sandalc1lar, A. Z. (2012). "Correlation between paper production and economic development in Turkey: A co-integration and causality analysis," C.U. Journal of Economics and Administrative Sciences 13(2), 1-15.

SKVS (2015). Pulp and Paper Industry Foundation, 2015 Annual Report, Istanbul, Turkey.

Snarr, J., and Pezza, K. (2000). Recycling Guidebook for the Hospitality and Restaurant Industry, Department of Environmental Programs, Washington, DC. 
Steg, L., and Vlek, C. (2009). "Encouraging pro-environmental behavior: An integrative review and research agenda," Journal of Environmental Psychology 29(3), 309-317.

TEDAS (2016). "Electricity tariff in 2016," (TEDAS: Turkish Electricity Corporation), (http://www.tedas.gov.tr/\#!tedastarifeler), accessed 14 April 2016.

The Royal Society (2012). People and the Planet, the Royal Society Science Policy Centre Report 01/12, ISBN: 978-0-85403-955-5, London, UK.

THF (2017). “Legislation,” (THF: Turkish Hoteliers' Federation), (http://www.turofed.org.tr/genelgeler.html), accessed 12 June 2017.

TR Central Bank (2016). "Foreign Exchange Rates," (http://www.tcmb.gov.tr/kurlar/201512/31122015.xml), accessed 13 June 2016.

TR Ministry of Culture and Tourism (2011). "Istanbul's Historic Peninsula Management Plan," (in Turkish), (http://www.alanbaskanligi.gov.tr/files/Y\%C3\%B6netim\%20Plan\%C4\%B1_24\%C5 \%9Fubat2012_k.pdf), accessed 13 July 2017.

TR Ministry of Energy and Natural Resources (2016). "What is the meaning of carbon capture and storage?” (http://www.eie.gov.tr/teknoloji/ccs_nedir.aspx), accessed 16 July 2016.

TR Ministry of Forest and Water Affairs (2017). "A new road map for special forestation from the Forest and Water Affairs," (http://www.ormansu.gov.tr/haber/orman-ve-sui-şleri-bakanlığı-ndan-özel-ağaçlandırmaya-yeni-yol-haritası), accessed 6 July 2017.

TR Ministry of Forest and Water Affairs (2016). "Operations of production and marketing in forest administration," (http://docplayer.biz.tr/ 5573277- Orman-genelmudurlugu-isletme-ve-pazarlama-daire-baskanligi.html), accessed 16 April 2016.

TR Ministry of Science, Industry and Technology (2013). "National recycling strategy document and action plan 2014-2017,"

(http://www.resmigazete.gov.tr/eskiler/2014/12/20141230M1-12-1.pdf), accessed 16 June 2016.

TR Ministry of Environment and Forest (2008). "Waste Management Action Plan (20082012)," Ankara

TBB (2011). "Regulations on Environmental Law and Solid Waste Management," (TBB: Union of Turkish Municipalities) (in Turkish), 968 p., Ankara, Turkey

TSI (2017). "Main Statistics," (TSI:Turkish Statistical Instutite) (http://www.turkstat.gov.tr/UstMenu.do?metod=temelist), accessed 11 June 2017.

TUROB (2013a). "Istanbul accommodation capacity," (TUROB: Hotel Association of Turkey), (http://www.turob.com/projeler.aspx), accessed 11 June 2017.

TUROB (2013b). $360^{\circ}$ Degree Evaluation of Istanbul's Hotels, Research Project Report, (in Turkish), (http://www.turob.com/bulten/360.html), accessed 13 June 2017.

TÜBİTAK (2003). Environment and Sustainable Development Thematic Panel Report. Vision 2023: Science and Technology Strategies for Technology Foresight Project, (TÜBİTAK: Turkey Scientific and Technological Research Corparation), Ankara, Turkey.

Turizm Ajans1. (2017). "Turkey's certified bed capacity approached 1 million," (http://www.turizmajansi.com/haber/turkiye-nin-belgeli-yatak-kapasitesi-1-milyonayaklasti-h5686), accessed 16 February 2017.

UNWTO (2016a). "Strong tourism results in the first part of 2017, World Tourism Barometer, Madrid: World Tourism Organization Press," 
(http://cf.cdn.unwto.org/sites/all/files/pdf/unwto_barom17_03_june_excerpt_1.pdf), accessed 12 June 2017.

UNWTO (2016b). "Tourism Highlights," (http://www.eunwto.org/doi/pdf/10.18111/9789284418145), accessed 6 June 2017.

UNWTO (2017a). "World Conference on Tourism and Future Energy: Unlocking lowcarbon growth opportunities," (http://www.cvent.com/events/world-conference-ontourism-and-future-energy-unlocking-low-carbon-growth-opportunities/custom-119a4301c2fa71a4d82979b870bc5a70cdd.aspx?RefID=Home), accessed 14 June 2017.

UNWTO (2017b). "Bulletin No: 64," (http://www2.unwto.org/content/unwto-news-64),

van Kooten, C., Bulte, E. H. (2000). The Economics of Natural Resoure, Managing Bilogical Assets, ISBN 0-631-21895-5, Blackweel Publishers Inc. USA.

Virtanen, Y., and Nilsson, S. (2013). Environmental Impacts of Waste paper recycling, ISBN 1855383-160-3, Earthscan Publications Limited. USA and Canada.

Worlbank (2016).’International tourism, receipts (current US\$)," (http://data.worldbank.org/indicator/ST.INT.RCPT.CD), accessed 26 June 2017.

WBCSD (2012). "Future from fibre from forest to finished product," (WBCSD:World Business Council for Sustainable Development), (http://apki.net/wpcontent/uploads/2012/12/Future-from-Fibre-From-Forest-to-Finish-Product.pdf), accessed 13 April 2017.

WBCSD (2016). "We help procurement managers make informed choices about wood and paper-based products," (http://sustainableforestproducts.org/sites/default/files/2016-09/Recycled_Fibers.pdf), accessed 16 Feb. 2016.

Yakut, A. (2012). "Examination of paper production out of recyclable waste paper," Installation Engineering (127), 68-75.

Y1kmaz, R. F. (2011). Measurement of Sustainable Development and its Method Development for Turkey, State Planning Agency Publications, Ankara, Turkey.

Y1ldiz, Z. (2011). Development of tourism sector and its effects on employment, Suleyman Demirel University, The Journal of Visionary, 3(5), 54-71.

Yildızbaş, F. (2007). "Waste recycling and economic benefits in Karaman Province," Selçuk University, Karaman I.I.B.F. Journal Local Economics, Konya, Turkey.

Y1lmaz, A., and Bozkurt, Y. (2010). "Urban solid waste management applications in Turkey and KUKAB Case," Suleyman Demirel University, Journal of Faculty of Economics and Administrative Sciences 15(1), 11-28, Isparta, Turkey.

Yorulmaz, H. (2014). "East Marmara region waste paper report," Regional Plan Publications Series 16, (http://www.dogumarmarabolgeplani.gov.tr/pdfs/ kagit_raporu.pdf), accessed 16 June 2016.

Zhang, B., Bi, J., Yuan, Z., Ge, J., Liu, B., and Bu, M. (2008). "Why do firms engage in environmental management? An empirical study in China," Journal of Cleaner Production 16(10), 1036-1045.

Zso'ka, Á. (2008). 'Consistency and 'awareness gaps' in the environmental behaviour of Hungarian Companies," Journal of Cleaner Production 16, 322-329

Article submitted: April 18, 2017; Peer review completed: June 25, 2017; Revised version received: July 17, 2017; Accepted: July 25, 2017; Published: August 3, 2017. DOI: 10.15376/biores.12.4.6924-6955 